\title{
Early Ordovician trilobites and molluscs from the Poulsen Cliff Formation, Washington Land, western North Greenland
}

\author{
RICHARD A. FORTEY AND JOHN S. PEEL
}

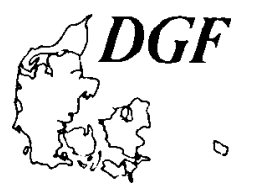

\begin{abstract}
Fortey, R. A. \& Peel, J. S.: Early Ordovician trilobites and molluscs from the Poulsen Cliff Formation, Washington Land, western North Greenland. Bull. geol. Soc. Denmark, vol. 38, pp. 11-32, Copenhagen, April 25th, 1990. https://doi.org/10.37570/bgsd-1990-38-02

A well-preserved, shallow water bathyurid trilobite fauna of early Ordovician age, and associated gastropods and an undetermined hyolith are described from the Poulsen Cliff Formation of Washington Land, western North Greenland. Two new bathyurid species, Licnocephala sminue and Peltabellia elegans, and a new gastropod species, Plethospira(?) floweri, are described. Biolgina Maximova is considered a junior subjective synonym of Peltabellia Whittington. The distribution of the genus is an example of close relationship between shallow water trilobite faunas of Laurentia and the North-east Siberian platform in the early Ordovician.
\end{abstract}

R. A. Fortey, Department of Palaeontology, British Museum (Natural History), London SW75BD, U.K. J. S. Peel, Geological Survey of Greenland, Oster Voldgade 10, DK-1350 Copenhagen K, Denmark. November 21st 1988.

The fossils described in this paper were collected from the Poulsen Cliff Formation by J. S. P. in 1976 during regional geological investigations in Washington Land and Daugaard-Jensen Land (figs 1,2 ) undertaken by the Geological Survey of Greenland (1975-1977); preliminary determinations were recorded in a short note by Fortey \& Peel (1982). Prior to this period the Poulsen Cliff Formation had not yielded macrofossils. The trilobites are well-preserved and the forms recovered are of some biogeographic interest, emphasising the close relationship between shallow water trilobite faunas of Laurentia and North-east Siberia during the Early Ordovician. The bathyurids Licnocephala and Peltabellia are described from Greenland for the first time, although Cowie \& Adams (1957, p. 36) reported a tentative identification of the latter genus in a list of the fauna of the Cape Weber Formation of East Greenland. The gastropod fauna includes species of Archinacella(?), Bridgeina, Plethospira(?), Hormotoma and Sinuopea, the first three of which are also described for the first time from Greenland. Trilobites and gastropods occur together with an undetermined hyolith, described below, and poorly preserved syntrophiid brachiopods.

The Poulsen Cliff Formation was originally de- scribed by Troelsen (1950) from a section in a gully south-west of Nygaard Bugt, southern Washington Land (fig. 1). Earlier cartographic and geological exploration of the area by Lauge Koch failed to locate this stratigraphic interval and its faunas are consequently missing from the otherwise comprehensive monograph prepared by Poulsen (1927) on the basis of Koch's collections. The Poulsen Cliff Formation was referred to the Ryder Gletscher Group by Ineson \& Peel (1987), a series of platform interior carbonates and associated siliciclastic sediments forming part of the Lower Palaeozoic Franklinian Basin sequence of Arctic Canada and adjacent North Greenland (Higgins $e t$ al. in press). As originally noted by Troelsen (1950), many of the lithostratigraphic units present in the Washington Land area of Greenland can be traced westward into Ellesmere Island (Peel \& Christie 1982). In this latter area, strata equivalent to the Poulsen Cliff Formation are referred to the lower member of the Baumann Fiord Formation (Kerr 1967; 1968).

The Poulsen Cliff Formation comprises some 100-125 m of shales, dolomites and thin sandstones, and contains evaporites. The evaporites are probably subaqueous deposits which accumulated in a shallow hypersaline basin extending 


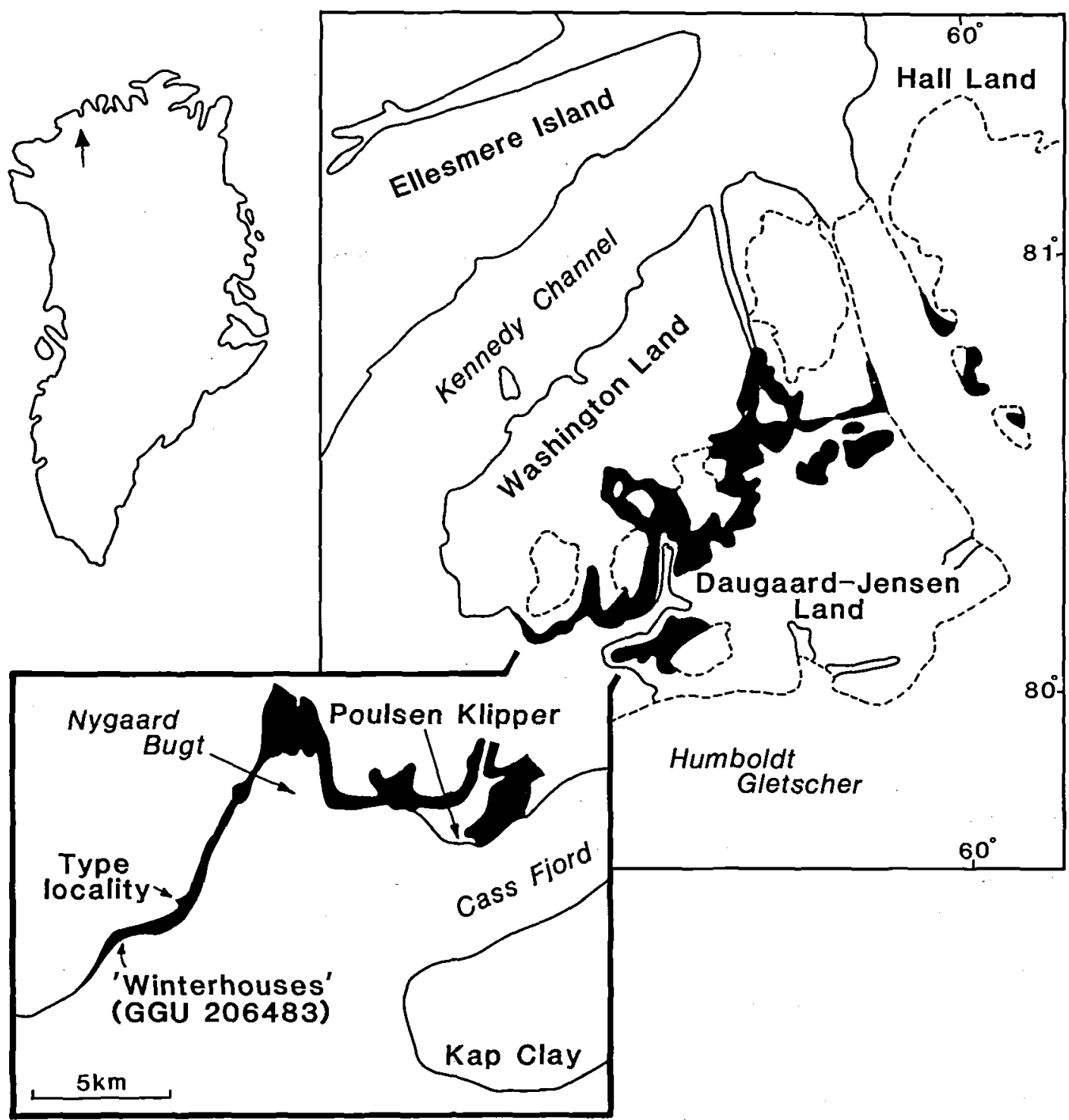

Fig. 1. The Washington Land region of western North Greenland showing outcrops of Lower Ordovician (black). Inset map of the area around Nygaard Bugt indicates the collection locality for fossils described herein and the type locality for the Poulsen Cliff Formation, as described by Troelsen (1950); outcrops of the Poulsen Cliff Formation (thickness about $100 \mathrm{~m}$ ) and the overlying Nygaard Bay Formation (about $40 \mathrm{~m}$ ), together equivalent to the Baumann Fiord Formation of Ellesmere Island, are indicated in black.

across Ellesmere Island and into western North Greenland (Mossop 1979; Peel \& Christie 1982). All the fossils described here were recovered from within a $1 \mathrm{~m}$ thick, mound-like bed of digitate stromatolites (GGU collection 206483) collected some $48 \mathrm{~m}$ below the top of the formation near the abandoned eskimo dwellings ('Winterhouses') south-west of Nygaard Bugt (fig. 1). The lime mud in which they are preserved has allowed them to retain their full relief, but all the trilobites are disassociated parts. Only two trilobite genera (each with one species) are present, of which Peltabellia is much the commonest. The five species of gastropods in the same fauna occur mainly as internal moulds, and are associated with rare hyoliths and poorly preserved syntrophiid brachiopods. 


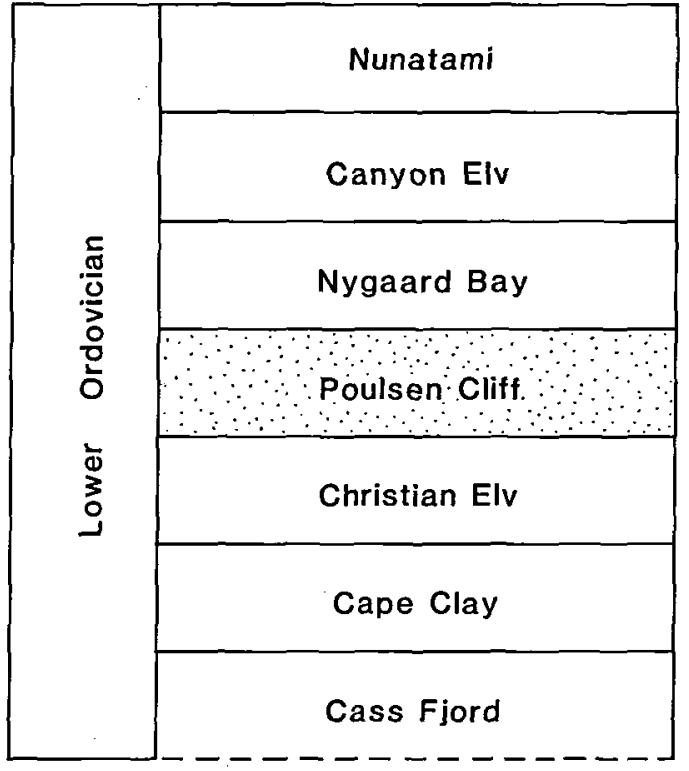

Fig. 2. Lower Ordovician formations in the Washington Land area, western North Greenland.

\section{Biofacies and age}

It is not surprising that the only trilobites found in the shallow water deposits of the Poulsen Cliff Formation belong to the family Bathyuridae. This family was characteristic of inshore calcareous facies over a huge area of the Ordovician palaeoequatorial region, stretching from New Mexico to Ellesmere Island and Greenland in Laurentia, but also in North-east Siberia and the North China platform (below). The family dominates the shallower water earlier Ordovician trilobites faunas of Greenland (Poulsen 1927, 1937). The most recent addition to these occurrences was a fauna from the Wandel Valley Formation of eastern North Greenland, slightly younger than the present fauna (Fortey 1986; Fortey \& Peel 1983), of which some individual species have ranges extending over much of Laurentia. Such bathyurid faunas are best regarded as an inshore biofacies ('province' in the sense of Whittington 1963) which may become established on the carbonate platform wherever conditions were locally suitable. Bathyurids are accompanied by conodonts of the North American 'Midcontinent Realm', as they are in the Poulsen Cliff Formation by a fauna of conodont Fauna D (Kurtz \& Miller in Fortey \& Peel 1982) age.
The base of Fauna D, indicated by the first appearances of Glyptoconus quadriplicatus (Branson \& Mehl) and Eucharodus parallelus (Branson \& Mehl), is $22 \mathrm{~m}$ below GGU 206483, although a $63 \mathrm{~m}$ stratigraphic interval below this point has not yielded conodonts. Further additions to the Fauna D assemblage are made $32 \mathrm{~m}$ above the macrofauna described herein, where Drepanodus concavus (Branson \& Mehl) and "Scolopodus" emarginatus Barnes \& Tuke are introduced. The base of the Oepikodus communis Zone, marked by the first appearance of the nominate species, is $150 \mathrm{~m}$ above GGU 206483, a short distance above the base of the Nunatami Formation (fig. 2; M. P. Smith, written communication 1988).

The Poulsen Cliff Formation fauna is of interest in the context of this familiar biogeographic model because one of the bathyurids, here assigned to Peltabellia, is comparable, if not identical, at specific level to species from the carbonate platform of north-eastern Siberia. The implication is that the Siberian platform, in terms of trilobite biofacies, was sufficiently comparable to Ordovician Laurentia for the common occurrence of an inshore trilobite species; nor was the Franklinian sea a barrier to the distribution of such taxa.

As far as age is concerned, both Peltabellia and Licnocephala are recorded from Utah and Nevada through a fairly short mid-Canadian interval, embracing trilobite Zones $F$ and $G$ of Ross (1951) and Hintze (1952). This early bathyurid fauna invariably underlies a much more diverse bathyurid fauna of the kind described from the Wandel Valley Formation, with Petigurus, Jeffersonia, Punka, etc, spanning trilobite Zones $\mathrm{H}$ through I, J. In terms of the British standard series the Tremadoc-Arenig boundary, although difficult to correlate precisely, appears to lie within the upper part of Zone $G$ or close to the base of Zone H. Occurrences of Peltabellia-like species in Siberia and northern China have been correlated with the late Tremadoc or early Arenig. On generic association, the age of the Greenland fauna is certainly early Ordovician; with a possible range spanning the late Tremadoc to early Arenig it is compatible with conodont Fauna D. At species level, the direct comparison is with the fauna of the Rich Fountain Formation (Cullison 1944) of the Ozark Uplift, Missouri. 


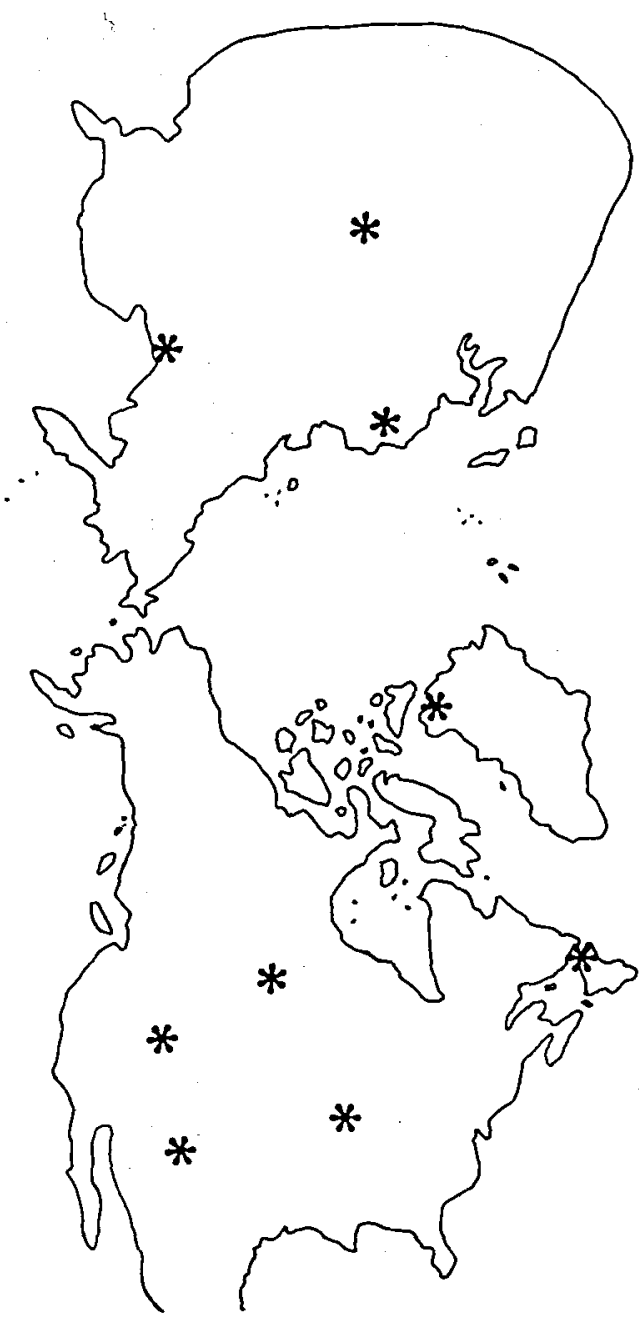

Fig. 3. Distribution of the inshore bathyurid trilobite Peltabellia over Laurentia and the Siberian platform. Location of Russian examples in Vinogradov et al. (1968); further occurrences discussed in text, although data point in western Newfoundland was recorded in Boyce (1983).

This fauna underlies that of the Cotter and Powell dolomites previously compared at species level (Fortey 1979) with the bathyurid fauna of the Catoche Formation, St George Group, western Newfoundland. This latter is Billings' (1865) classic "Late Canadian" fauna and probably correlates with that from Zones $\mathrm{H}$ and $\mathrm{I}$ of $\mathrm{Utah}$ and Nevada, like that of the Amdrup Member of the Wandel Valley Formation (Peel \& Smith 1988). The implication is that the Poulsen Cliff fauna is likely to be of Zone $F$ or $G$ age - hence late Tremadoc rather than Arenig; the conodonts sug- gest that Zone F is more likely (M. P. Smith, written communication 1988).

\section{Distribution of Peltabellia}

Western North Greenland lies geographically between the main part of the Laurentian palaeocontinent and the North-east Siberian platform. The detailed taxonomic treatment of Peltabellia given below shows that Siberian species referred to the genus Biolgina Maximova are very probably congeneric. Indeed, it is difficult to prove specific differences between material from Siberia, Greenland and Missouri. Fig. 3 shows the distribution of Peltabellia over this area. Data on Siberian distribution are taken from palaeogeographic maps published by Vinogradov et al. (1968). The genus is confined to the carbonate platform there, providing a direct comparison with the bathyurid biofacies of North America and Greenland. Other typical bathyurids, for example Punka (to which genus Bathyurellus nordicus Chugaeva 1968 is referred), are found in North-east Siberia. A species referred with question to Peltabellia has also been described from the North China platform (Zhou \& Fortey 1986).

It is clear that the bathyurid biofacies extended from Laurentia to Siberia and possibly into North China in the Lower Ordovician. There was no effective barrier around this part of the palaeoequatorial great circle, even for what are presumably quite stenotopic forms, being the inhabitants of inshore stromatolitic habitats. In the Upper Cambrian there has been a tendency to employ different taxonomy in describing Siberian and North American platform trilobites, and it does seem possible that there will be other examples of widespread taxa once the synonymy is resolved.

\section{Relationship of the gastropod fauna}

Maximova (1955) described two new species of Biolgina from the Chunsk Stage of Siberia. In the same volume; Vostokova (1955) described ac companying gastropods, noting a fauna with Ophileta, Ecculiomphalus, Proplina, Archinacella and "Palaeacmaea"; the fauna was also described again by Vostokova (1962). Only Archinacella is shared between the Siberian fauna and 
that of the Poulsen Cliff Formation but the species are not similar.

The mollusc fauna of the Rich Mountain Formation of the Ozark uplift described by Cullison (1944) appears to share Archinacella(?) elongata (Cullison 1944) with the Poulsen Cliff Formation, but the accompanying species of Orospira, Hormotoma and "Proplina" are unlike the Greenland fauna.

Large planispirally coiled gastropods are characteristic of many Lower Ordovician faunas (e.g. Flower 1969a-c; Heller 1954) but are absent from the currently described fauna from the Poulsen Cliff Formation. This difference may reflect the association of the Poulsen Cliff gastropods with stromatolite mounds. All fossils described in the present paper were collected from within one such mound where they occur in the interspaces between the closely spaced, $1-2 \mathrm{~cm}$ wide individual stromatolite digitations.

\section{Systematic descriptions}

Authorship. - R. A. F. is responsible for the description and discussion of the trilobites while J. S. P. has prepared sections concerned with molluscs. We assume joint responsibility for the authorship of new taxa.

\section{Class Trilobita}

\section{Family Bathyuridae Walcott 1886}

Subfamily Bathyurellinae Hupé 1953

Remarks. - The subfamily Bathyurellinae comprises bathyurids with large, usually transverse pygidia having flattened borders; the glabella falls short of the cephalic margin (it may become effaced also), and the genal spines are broadly triangular and blade-like. Fortey $(1979$, p. 74$)$ referred Bathyurellus, Punka, Uromystrum, Licnocephala, and probably Grinellaspis to the subfamily. The Early Ordovician species from Greenland considered here are stratigraphically older than the late Canadian to Middle Ordovician bathyurellines in which the generic characters are clearly distinct, and provide evidence of the likely primitive morphology of the group. Licnocephala is like Punka and Uromystrum in some important features: the broad cephalic bor- der, and very long genal spines, and wide pygidium with distinctly demarcated border. Peltabellia is now also referred to the subfamily. Its pygidial border is wide, but can be sloping rather than flattened; the preglabellar field is also wide, although steeply inclined; the genal spines are shorter than those of other bathyurellines, but the broadly triangular form on the species from western North Greenland is essentially similar in construction. Note that both species attributed here to Licnocephala and Peltabellia have similar glabellar shape, relatively short and broadly rounded anteriorly, when compared with stratigraphically younger bathyurellines, which have elongate glabellas that may be acuminate anteriorly. It is presumed that the subrectangular glabellar shape is primitive, because it is also present on earlier bathyurines such as Goniotelina (Ross 1951, pl. 14, fig. 21). Later bathyurellines do not have tuberculate or granulose exoskeletal surfaces, and the Greenland species is like this also, whereas granulose or even coarsely tuberculate sculpture is common in bathyurines, as it is on the presumed bathyurid sister group Hystricurinae. However, the type species of Peltabellia, $P$. peltabella, is also granulose, and again this seems likely as a retained primitive character. Peltabellia is appropriate, both morphologically and stratigraphically, as a primitive bathyurelline 'stock'.

\section{Genus Licnocephala Ross 1951}

Type species. - L. bicornuta Ross 1951, original designation.

Diagnosis. - Bathyurellines with broad and flat cephalic border; preglabellar field present; long falcate genal spines; very wide (tr.) pygidium with wide border on to which pleural furrows do not continue.

Remarks. - Ross (1951) originally tentatively assigned a pygidium to the type species (his pl. 30, fig. 25). He chose to emphasize the low (sag.) cephalic convexity of the type species as one of the generic characters. Hintze (1952) subsequently described $L$. cavigladius (additional material in Ross 1953, pl. 64), with a definitelyassigned pygidium similar to Ross' specimen although less transverse. The pygidia of the present material are also consistent with such an associ- 


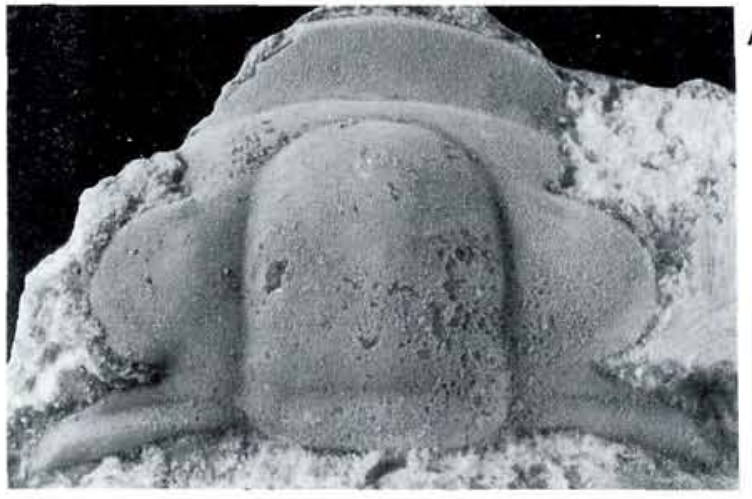

A B
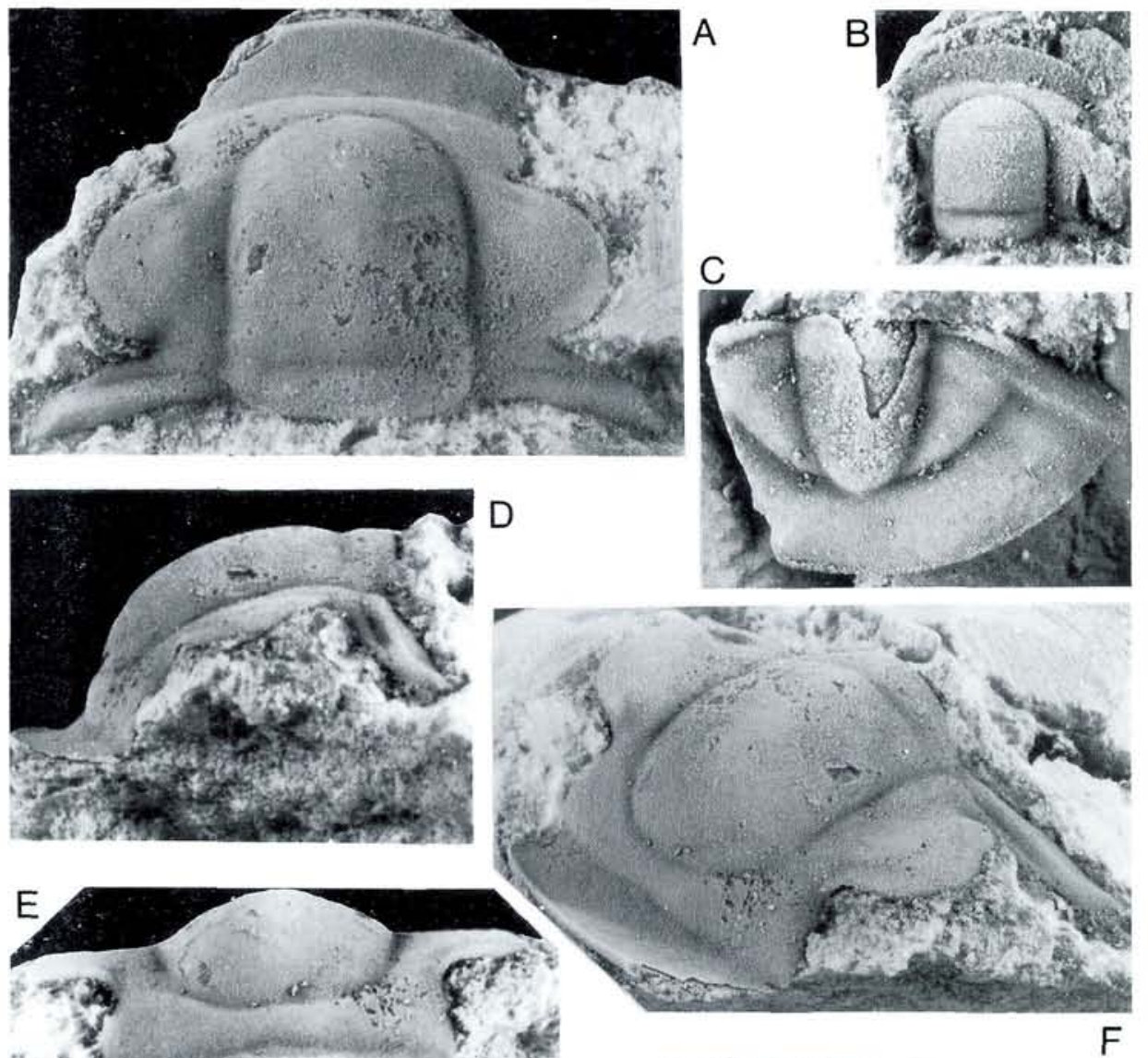

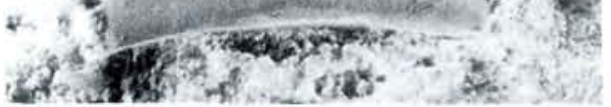
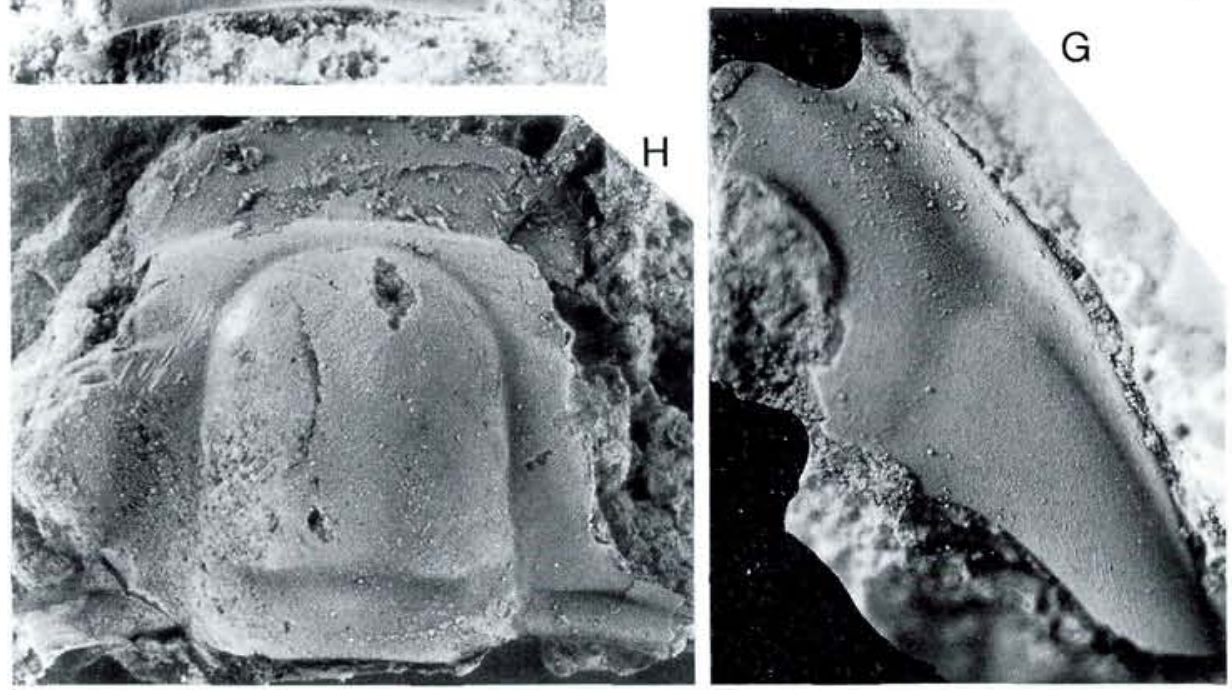

Fig. 4. Licnocephala sminue sp. nov. Poulsen Cliff Formation, GGU collection 206483, all X6. A, D-F, well preserved cranidium in dorsal, lateral and oblique views, MGUH 18.953. B, smallest cranidium, dorsal view, MGUH 18.954. C, incomplete small pygidium, dorsal view, MGUH 18.955. G, free cheek, genal spine incomplete. MGUH 18.956. H, large cranidium, incomplete on right side, MGUH 18.957. 
Fig. 5, Licnocephala sminue sp. nov, Poulsen Cliff Formation, GGU collection 206483, all X5. A, exfoliated pygidium, showing very faint indications of pleural furrows on the border, MGUH 18.958 . $\mathrm{B}, \mathrm{C}$, holotype, large pygidium in dorsal and posterior views; note the lack of surface sculpture. MGUH 18.959.
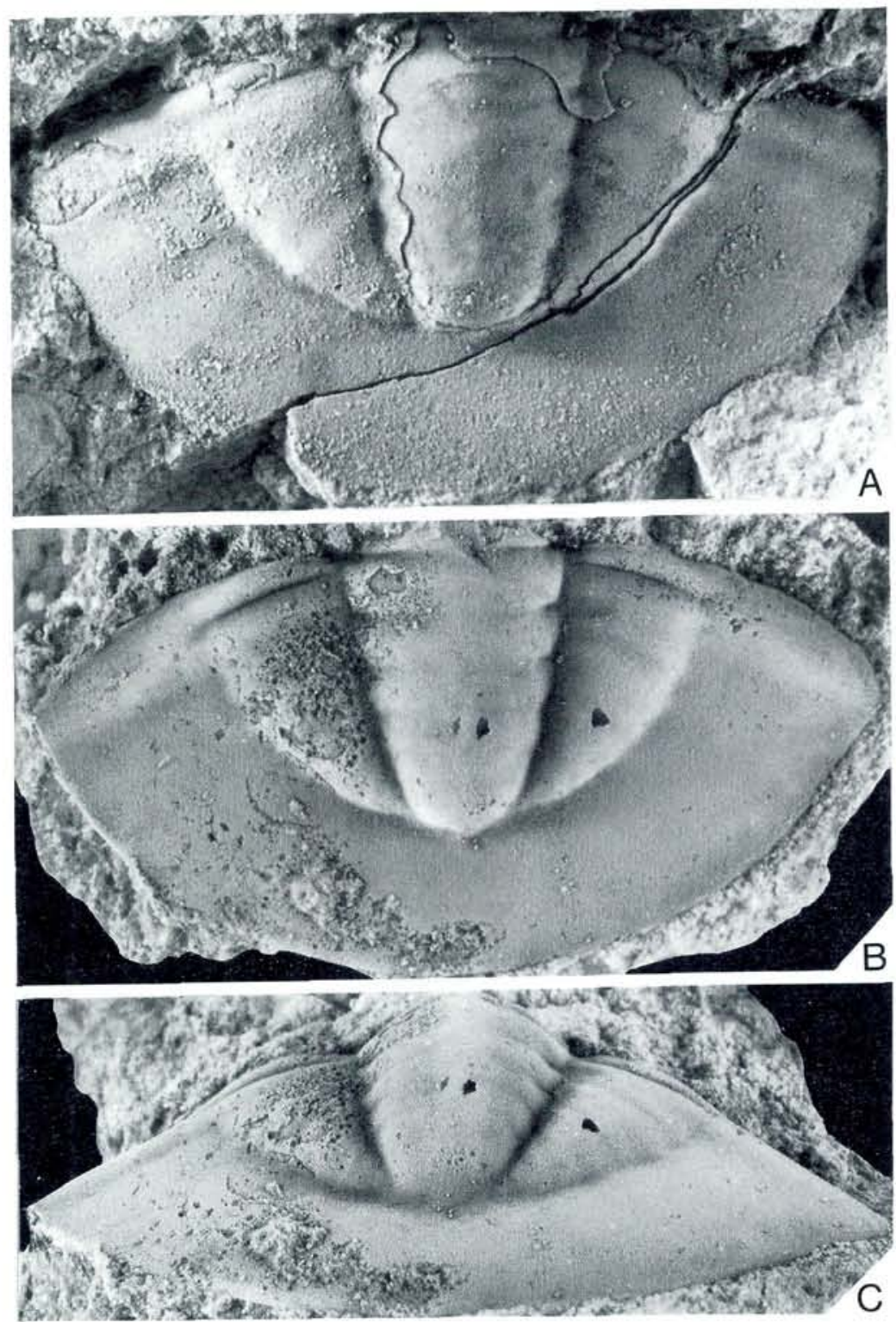

ation. Cephalic convexity is a rather variable character in bathyurellines as can be seen by comparing bicornuta, cavigladius and sminue (below). By contrast, pygidial characters have proved consistent in the definition of likely monophyletic bathyurid genera, and it is preferred here to place emphasis on the wide pygidium, with an arcuate posterior outline, having a wide or very wide unfurrowed border. Pleural furrows are concentrated on a relatively small, convex adaxial area, which may or may not be sharply demarcated from the border. All species also have a broad cephalic border which narrows into the proximal part of the long and falcate genal spine. 
Licnocephala sminue sp. nov.

Figs 4, 5

? 1944. Bathyurellus permarginatus Cullison (pars): Cullison, pl. 34, fig. 24 non fig. 23.

Holotype. - Pygidium with exoskeleton, MGUH 18.959 from GGU collection 206483.

Paratypes. - MGUH 18.953 - 18.958; all from GGU collection 206483.

Name. - Greek, a tool for tilling, referring to the form of the genal spines.

Diagnosis. - Licnocephala with cranidium more convex (sag.) than others of the genus, and glabella more subrectangular; pygidium with axis two-thirds pygidial length, and border clearly demarcated from pleural fields; pygidial pleural furrows indistinct.

Description. - Cranidium moderately convex (sag.), with preglabellar field nearly vertical. Maximum width at posterior margin, this being 1.7 times sagittal length in dorsal view, and 1.2 times the width across the palpebral lobes. Glabella gently convex transversely, subquadrate (transverse width equal to sag. length in front of occipital ring) to gently tapering forwards, with broadly rounded front; larger cranidia show a slight constriction in glabellar width opposite the hind parts of the palpebral lobes. There is no indication of glabellar furrows. The occipital ring is relatively well defined, especially so on the small cranidium, and one-fifth to one-sixth total glabellar length. Occipital furrow nearly transverse, somewhat effaced at outer ends, where curving a little forwards. Axial furrows narrow and of uniform depth (deeper on small cranidium); preglabellar furrow equally well-defined. Palpebral lobes large and nearly semicircular, half, or slightly more than half the length of glabella, posterior limits not far in front of occipital furrow, and anterior limits close to glabella; rims flattened, subdued, and continued inwards as weak eye ridges which run into axial furrows at rounded anterior corners of glabella. Postocular cheeks narrow and strip-like, gently declined to a point. Posterior border furrow not deep, especially adaxially, defining a rather convex post- erior border. Preglabellar field slightly convex, narrowest mesially. Anterior border flat, or gently concave, broad, sagittal length exceeding that of occipital ring in dorsal view, widest medially, where it makes a distinct embayment in the preglabellar field; very narrow, slightly upturned rim. Facial sutures highly divergent behind eyes, much less so in front of eyes, curving adaxially across border to meet a mid line.

Free cheek elongate-triangular, produced into broad-based genal spine (incomplete on available material). Convex genal field separated from spine by distinct, but shallow furrow which runs slightly outwards forwards. Cranidial border continues on to anterior part of cheek, but narrows gradually into proximal part of genal spine, and was not present on distal part of genal spine. Main part of genal spine convex and outwardsloping. Both cranidium and cheek were apparently without surface sculpture, apart from dense and very fine terrace ridges arranged en echelon along posterior margin of genal spine.

Pygidium with width twice, or slightly less, the sagittal length. Border wide, half the length of the axis. Axis occupies only a quarter of total pygidial width, and tapers gently posteriorly; it impinges slightly on to the border; its tip is broadly rounded, and well-defined. $\mathrm{Up}$ to four axial rings are visible, which are of equal length (exsag.), but only the first of these is weakly defined across the mid-part of the axis, the rest being indicated by the lateral parts of the ring furrows only; the axial rings are less well defined on the small pygidium; the terminal piece accounts for a quarter axial length. Gently convex pleural fields slope more steeply down to border, and are very weakly furrowed, apart from conspicuous anterior half-rib; up to three pairs of pleural furrows indicated, and even weaker interpleural furrows. Broadly triangular downturned facet which is wide laterally and extends inwards beyond border. Border slopes gently downwards, and is slightly convex. Pleural furrows do not pass on to border, or at most very weakly indicated on the large internal mould (fig. 5A). Boundary between adaxial pleural fields and border is very sharp, marked by an abrupt change in slope, especially noticeable on the small example (fig.4C). Surface smooth, entirely without sculpture. 
Discussion. - This species differs from the type species in the relatively steep downward slope of the preglabellar field, and it has much larger eyes. Ross' material is all small; our smallest cranidium has a proportionately larger glabella. The pygidium attributed to the type species is like that of the new species from Greenland in outline, but the axis is shorter, and the wider pleural fields more distinctly furrowed. None of these distinctions is considered likely to be of generic significance. L. cavigladius Hintze 1952 (see also Ross 1953) has a longer glabella than L. sminue, a much shorter pygidial axis, and a correspondingly extended border. The narrow pleural fields of this species are also furrowed. Ross (1951, pl. 30 , fig. 27) also figured an 'unassigned pygidium' which is much like that of the present species, and presumably represents another Licnocephala species in the Garden City Formation. It is distinguished from that of the new species in having a weakly convex axis, which may be somewhat funnel-shaped, and pleural fields which slope down gradually, not sharply to the border. Licnocephala ovata Ross 1953 is known from its cranidium; the glabella is strongly vaulted transversely, more like small cranidia of Punka than other Licnocephala spp. L. longa Kobayashi 1955 , known from pygidia, may be better referred to Punka.

Another species (as noted by Ross 1951, p. 77) which requires consideration is 'Bathyurus' amplimarginatus Billings 1859 (probably a senior synonym of $B$. minganensis Billings 1865 , see Twenhofel 1938, p. 71). This form is not completely known, but Twenhofel (1938 pl. 10, fig. 13) figured a pygidium from the Mingan Islands, Quebec, which shows abrupt truncation of the pleural furrows at a wide pygidial border, suggesting that a species of Licnocephala may be represented. The deep pleural and ring furrows are obvious distinctions from the new species. "Niobe" brevicauda Poulsen 1937 from East Greenland is like " $B$." amplimarginatus. Finally, one of the two pygidia attributed to Bathyurellus permarginatus and figured by Cullison (1944, pl. 34 , fig. 24) resembles the internal mould of $L$. sminue closely. This specimen is more transverse than the other specimen figured by Cullison, which is the holotype of permarginatus, and its articulating facet is less inclined backwards, in both respects resembling $L$. sminue.
Genus Peltabellia Whittington 1953

1955. Biolgina Maximova, p. 119

Type species. - Jeffersonia peltabella Ross 1951, original designation.

Remarks. - Whittington (1953) erected Peltabellia to incorporate the type species, which had been included in Jeffersonia, probably together with two species described under open nomenclature by Hintze (1952, pl. 9, figs 8, 11, 12, Jeffersonia? sp. B, and pl. 10, figs 7-10, Jeffersonia sp. A). Jeffersonia is a bathyurine closely similar to, if not identical with Bathyurina Poulsen (see Fortey 1986), and Whittington was surely correct in recognising the generic distinction of the species peltabella. Zhou \& Fortey (1986) drew attention to the close resemblance between Peltabellia and the genus Biolgina Maximova from the earlier Ordovician of the Siberian platform. The type species of Biolgina, B. sibirica Maximova, has been described by Maximova (1955, pl. 8, figs 4-7; 1962, pl. 3, figs 1-6) and Rozova (1968, pl. 17, figs 4-8), although the latter material apparently shows a longer pygidial axis and more flattened pygidial border when compared with the type description.

The close resemblance between $B$, sibirica and the species from the Poulsen Cliff Formation is indisputable, and they should be referred to the same genus. Significant similarities include: truncate glabellar form, with the occipital ring defined; steeply sloping preglabellar field; narrow cranidial border; short triangular genal spine separated from the genal field by a furrow; pygidium with deeply rounded posterior margin, sloping border, apparently unfurrowed, and convex pygidial axis more than half pygidial length, with four rings.

Additional species of Biolgina have been named from the USSR, $B$. brevis Maximova 1955 (pl. 8, fig. $2 ; 1962$, pl. 3, figs 7,8 ) and B. maximovae Chugaeva 1968 (pl. 6, figs 6-8; 1973, pl. 19, figs 1-3). The distinctive free cheek of the latter is nearly identical to that of the Poulsen Cliff species. However, these species attributed to Biolgina also resemble the type species of Peltabellia. The front margin of the glabella of $P$. peltabella is more rounded about the mid-line, and the genal spine is reduced to a stub. Neither of these differ- 

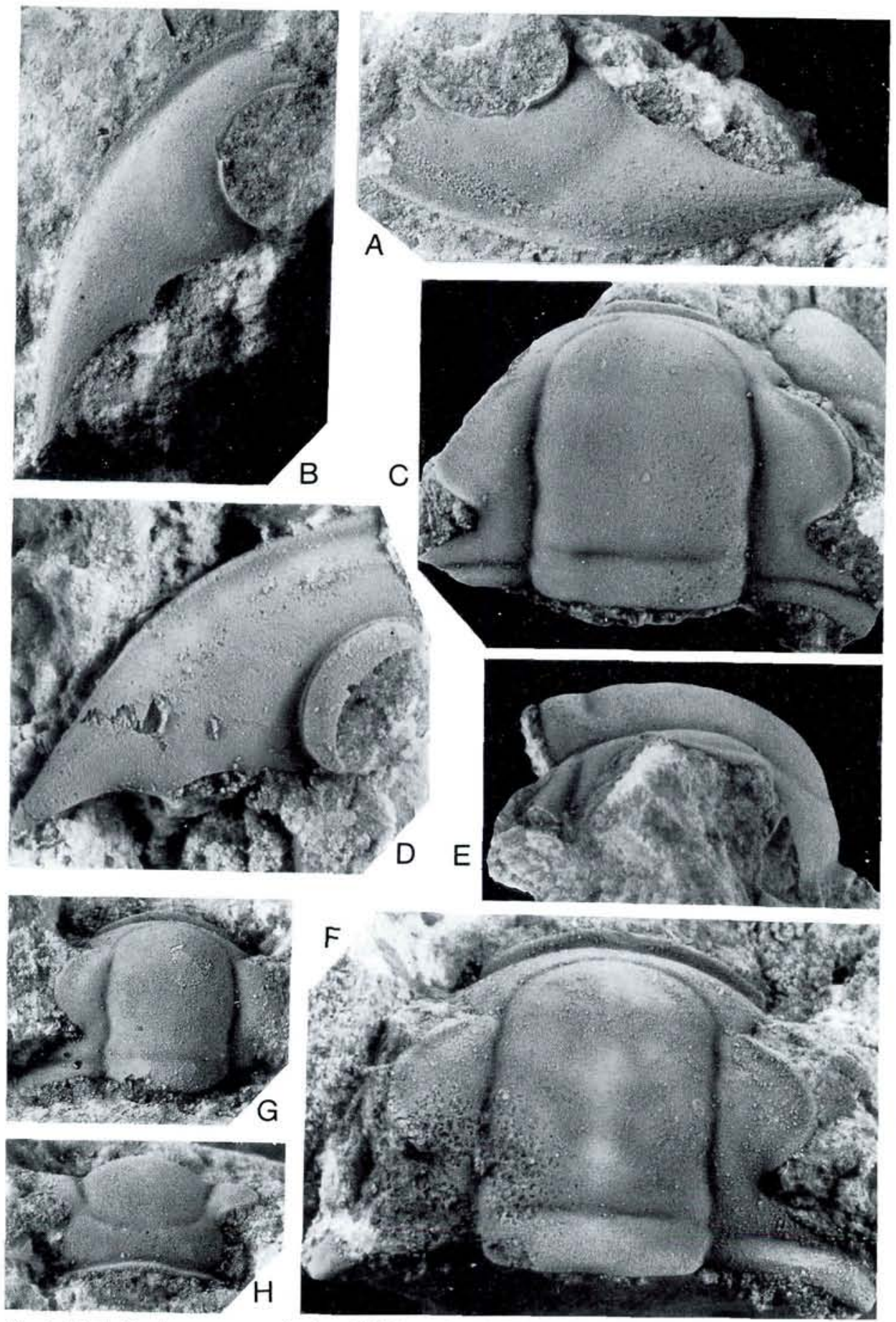

Fig. 6. Peltabellia elegans sp. nov. Poulsen Cliff Formation, GGU collection 206483, all X6. A, B, free cheek. anterolateral view to show furrow separating genal spine area from proximal part of cheek, MGUH 18.960 . C, E, cranidium, dorsal and lateral views, MGUH 18.961. D, free cheek retaining eye, oblique view to show eye socle, MGUH 18.962. F, largest cranidium, glabella tapers more forward than in smaller examples, MGUH 18.963, G, H. small cranidium, dorsal and anterior views, MGUH 18.964 . 

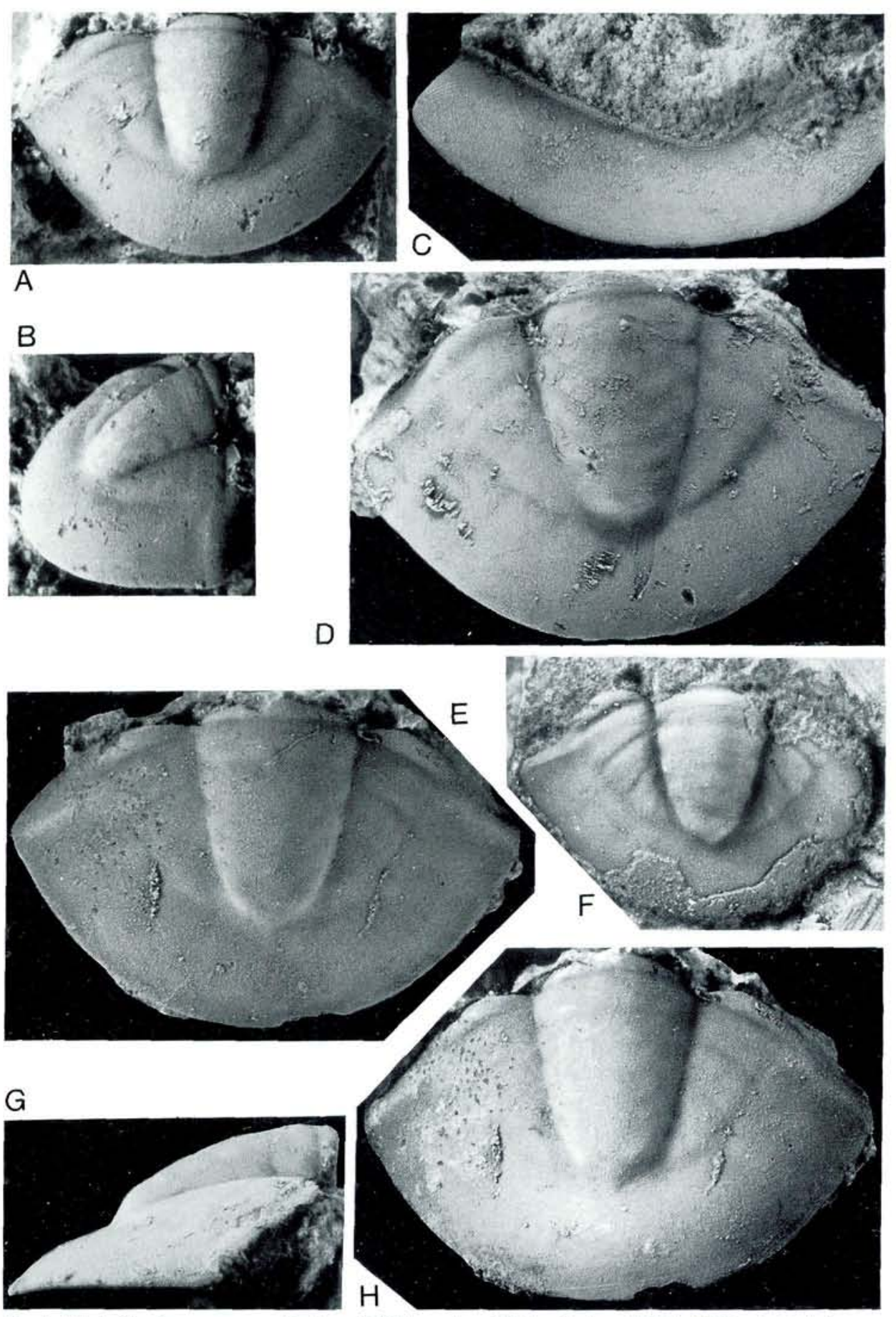

Fig. 7. Peltabellia elegans sp. nov, Poulsen Cliff Formation, GGU collection 206483, all X6. A, B, holotype, well-preserved pygidium in dorsal and oblique lateral views, MGUH 18.965. C, pygidial doublure from ventral side showing downturned rim, MGUH 18.966. D, same as C, but dorsal view. E, G, H, pygidium with indication of postaxial ridge, dorsal, lateral and postero-lateral views, MGUH 18.967. F, pygidium, dorsal view, MGUH 18.968. 
ences seem to merit generic separation. Also, the anterior view of the free cheek of $P$. peltabella (Ross 1951, pl. 17, fig. 7) shows that the area around the genal angle is inflated in a manner comparable with the species discussed above. Furthermore, the cheek of Hintze's (1952, pl. 9, fig. 12) "Jeffersonia" sp. B, also from Utah, which Whittington regarded as likely to belong to Peltabellia, has a proximally inflated genal spine like species attributed to Biolgina. No importance can be attached to the presence of granulose surface sculpture in the Utah species, as this is a primitive character for bathyurids as a whole (above). All these species share a relatively long (sag.) pygidium with a deeply curved posterior outline, and a smooth, but sloping border. The pygidium of the Greenland species is closely similar to one from the Lower Ordovician of Missouri.

In summary, there is no reliable morphological character to separate Peltabellia from Biolgina, and the latter is accordingly regarded as a junior subjective synonym. The species from western North Greenland forms a geographic link between species in the United States and those in Siberia (fig. 3), and can with equal facility be compared with both.

Diagnosis. - Bathyurellines having relatively short, inflated genal spines; cranidial border narrow (sag.); glabella subrectangular to anteriorly rounded; eyes medium-sized to large; pygidium with rather deeply rounded posterior outline; moderately wide pygidial border unfurrowed, downward-sloping and often gently convex; axis greater than half pygidial length, three or four axial rings.

Peltabellia elegans sp. nov.

Figs. 6, 7

Holotype. - Pygidium, MGUH 18.965 from GGU collection 206483 .

Name. - 'elegans', Latin, 'elegant'.

Paratypes. - MGUH 18.960 - 18.964, MGUH 18.966 - 18.968; all from GGU collection 206483.

Diagnosis. - Peltabellia with subrectangular glabella, short (sag.) preglabellar field; eyes large; triangular genal spines og moderate length; pygi- dium with gently convex, downward-sloping border; pygidal pleural fields not deeply furrowed; dorsal surface of exoskeleton almost without surface sculpture.

Description. - Cranidium widest at posterior margin, this being 1.6 to 2.0 times the sagittal length in dorsal view; width across palpebral lobes is about three-quarters maximum cranidial width. The whole cranidium is steeply downturned around the anterior margin, so that the cranidial profile is arcuate. In dorsal view the glabella thus extends far forwards, but even in small cranidia the preglabellar field is seen to extend over the mid-line in dorsal aspect. Glabella not greatly vaulted transversely, most markedly so across the occipital ring, and progressively less so anteriorly. Glabella form subrectangular, with broadly rounded front. On the largest cranidium (Fig. 6C) the glabella tapers forwards slightly, but on smaller specimens it is nearly parallel sided; width (tr.) slightly less than sagittal length from occipital ring to preglabellar furrow. Axial furrows narrow, and not deep; preglabellar furrow is shallower, but invariably defined. Glabella is slightly constricted on a level with the hind ends of the palpebral lobes; a slight bulge in glabellar width just in front of the constriction is most notable on smaller cranidia. Glabellar furrows are obscure: up to three pairs of very gentle depressions. The occipital furrow is well-defined, however, and is straight and transverse, on most specimens fading out just before reaching the axial furrows; the occipital ring so defined is onefifth to one-sixth total glabellar length, and of uniform width (sag., exsag.) along its length. Palpebral lobes large, gently sloping forwards, length (exsag.) ranging from slightly more to slightly less than half total glabellar length, the longer lobes on the smaller cranidia. Anterior ends of palpebral lobes close to glabella, and closer than posterior ends (transverse line connecting posterior limits of palpebral lobes at about one-third cranidial length). Palpebral outline almost semicircular, with stronger inward curve at posterior end; palpebral rims not welldefined, gently convex. Postocular cheeks narrowly triangular, two-thirds, or more on smaller cranidia, of the transverse width of glabella at occipital ring, gently downsloping. Posterior border elevated above cheek in front of it, especially 

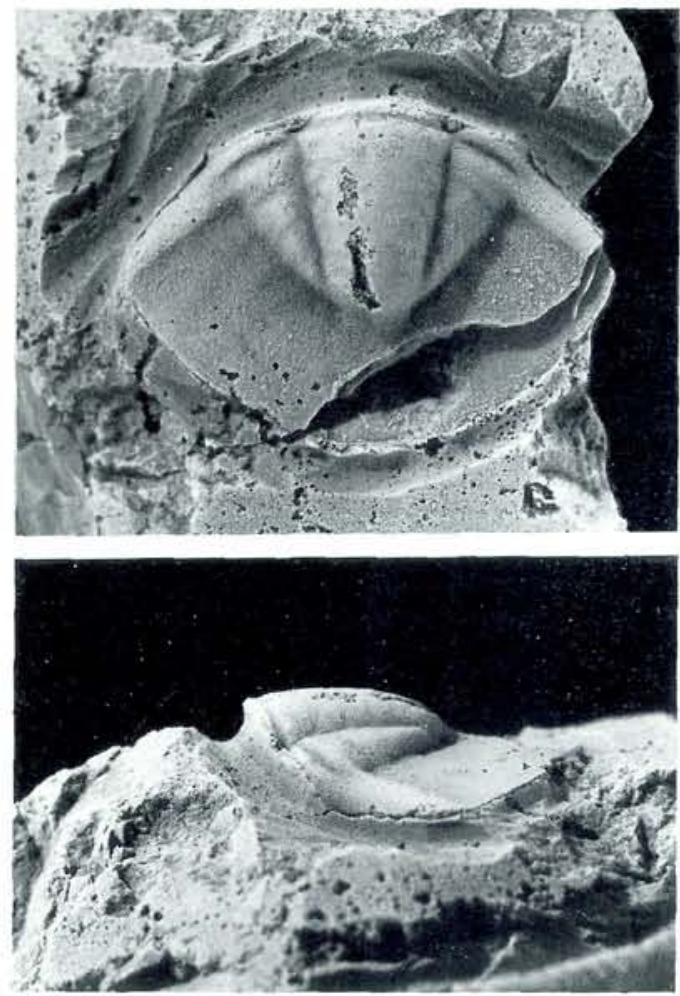

Fig. 8. Holotype of 'Bathyurellus' permarginatus Cullison 1944, from the Lower Ordovician Rich Mountain Formation of the Ozark region, dorsal and lateral views, $\mathrm{X} 4$, for comparison with Peltabellia elegans sp. nov. (Cullison 1944, pl. 34, fig. 23. Cast of original, YPM 17170, in Yale University collections).

laterally, and widening abaxially, defined by relatively narrow border furrow. Broad preglabellar field slopes steeply downwards, continuing forward slope of front of glabella, and is widest laterally. This downward slope is abruptly terminated at the cranidial anterior border, which is turned outwards horizontally, or nearly so, to a narrow and convex rim. In dorsal view the border and the preglabellar field appear about subequal in length (sag.) as a result of the foreshortening of the latter in this orientation. Facial sutures weakly divergent in front of palpebral lobes, and curving slightly adaxially across the border to meet at the mid-line; postocular sutures much more strongly divergent, 70 degrees or more to the sag. line. Surface smooth, or minutely punctate.

Free cheek produced into short, triangular genal spine, of length equal to, or shorter than eye. Anterior part continues downward slope of preglabellar field, laterally sloping downwards more gently; a gentle furrow running approximately exsagitally separates a convex area around the eye from another gently convex area which extends into the genal spine. Cephalic anterior border extends beyond this furrow, but becomes narrower, and is obsolete at the genal spine. Gently convex and strip-like eye is set up from cheek on a narrow eye socle (fig. 6D). Surface sculpture consists of about six narrow raised ridges which appear at about the edge of the genal spine, and run into it, approximately parallel to the cephalic margin.

Pygidia with width/length ratios in the range 1.3 to 1.8 , as measured in dorsal view, with maximum pygidial width at about 0.4 pygidial length. Axis well-defined, widest anteriorly, where it occupies one-third maximum pygidial width, and tapering gently posteriorly to rounded tip at about two-thirds pygidial length. Axial rings poorly defined, but some specimens show a weakly defined first ring over the mid-part of the axis. Lateral ends of ring furrows indicate the presence of four or five axial rings in total, and the best preserved material shows pairs of oval muscle impressions at the inner ends of the short, outer sections of ring furrows. A few specimens also show a suggestion of a post-axial ridge (fig. 7E). Pleural area divided into slightly convex, adaxial part and gently downsloping border, which is of similar width along its length, this being equal to the widest part of the pleural field at its anterior margin. The border furrow is not deep: rather it is a steeper slope at the outer edge of the convex, adaxial parts of the pleural fields. A steeply downturned facet extends inwards beyond the edge of the border. Pleural furrows generally weak, (other than on the short halfrib), two pairs, both sloping backwards, the second pair more so, and stopping at the border. The furrows are only at all clear on the internal mould (fig. 7F), on which there are very faint indications of interpleural furrows also. Dorsal surface without sculpture. Doublure reflexed horizontally (not back against dorsal surface as on most trilobites) and slightly narrower medially. Its inner edge is sharply downturned to form a narrow rim. It is interesting to note that the doublure is almost without terrace ridges over much of its surface (there are a few very fine ones around its periphery). This is an unusual feature in ptychoparioid doublures, especially wide ones. 

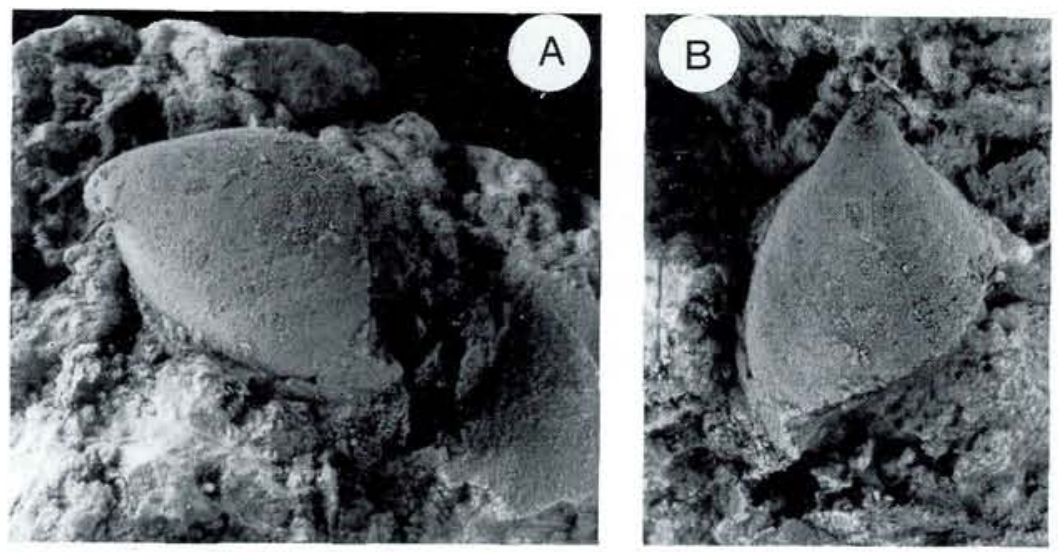

Fig. 9. Archinacella(?) cf. A.(?) elongata (Cullison 1944). Poulsen Cliff Formation, MGUH 18.970 from GGU collection 206483 , internal mould, all $\mathrm{X} 4$. A, oblique dorso-lateral view. $\mathrm{B}$, dorsal view. $\mathrm{C}$, oblique apico-dorsal view. $\mathrm{D}$, lateral view showing the strongly curved shell and the overhanging apex.
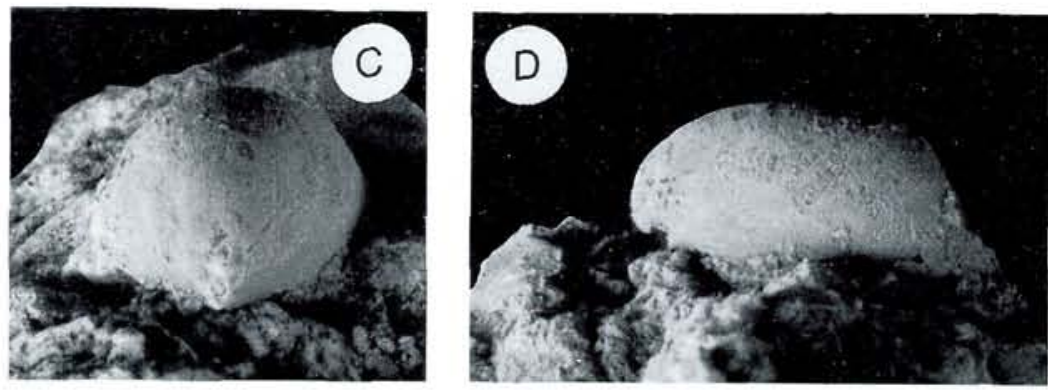

Discussion. - At first this species was regarded as identical with 'Bathyurellus' permarginatus Cullison 1944, described from two pygidia from Missouri (see fig. 8). Examination of the holotype of this species shows that in spite of general similarity in proportions the border in Cullison's species is horizontal, rather than sloping, and the edge of the pleural fields are more steeply defined. Because pygidia of bathyurids are often highly diagnostic, there seems sufficiant reason to separate the Greenland species as new. As indicated above the second pygidium illustrated by Cullison is similar to that of Licnocephala sminue. The pygidium of $P$. sibirica (e.g. Maximova 1962, pl. 3, figs 4, 6) from Siberia does not have such a clearly demarcated border, and the tip of the pygidial axis is distinctly truncate. Otherwise cephalic material of this species is much like that which has been associated with elegans pygidia in Greenland. The free cheek may show an abrupt end to the lateral border where it joins the genal spine (Maximova 1955, pl. 8, fig. 5), where on the Greenland specimens this border narrows gradually. However, the free cheek of $P$. maximovae Chugaeva (1968, pl. 6, fig. 8) is identical to the new species in this character. Probably the eye was shorter in this species, but the distorted or incomplete material figured hampers comparison, although it is clearly very close to $P$. elegans; no pygidium has been assigned to it.

Differences from the type species, $P$. peltabella (Ross 1951), were mentioned above; the longer genal spines of the Greenland form, its lack of surface sculpture, and its weakly furrowed pygidial axial and pleural lobes are obvious distinctions. Ross (1951, pl. 15, fig. 15) also figured what he considered to be the correct pygidium of "Jeffersonia" missouriensis Cullison 1944. This would clearly be accommodated within the concept of Peltabellia used here. The cranidia of this species figured by Cullison (1944, pl. 34, figs 10 , $12,13)$ are very like those from Greenland, although the palpebral lobes are certainly relatively short. Ross' pygidium is distinguished from those of elegans in having at least four well-defined axial rings, and a deeply scribed inner edge to the pygidial border. The close similarity of $P$. elegans and $P$. missourienses is otherwise obvious. A cranidium of similar type was figured from Utah (Zone G-2) as "undetermined gen. and sp. B" by 


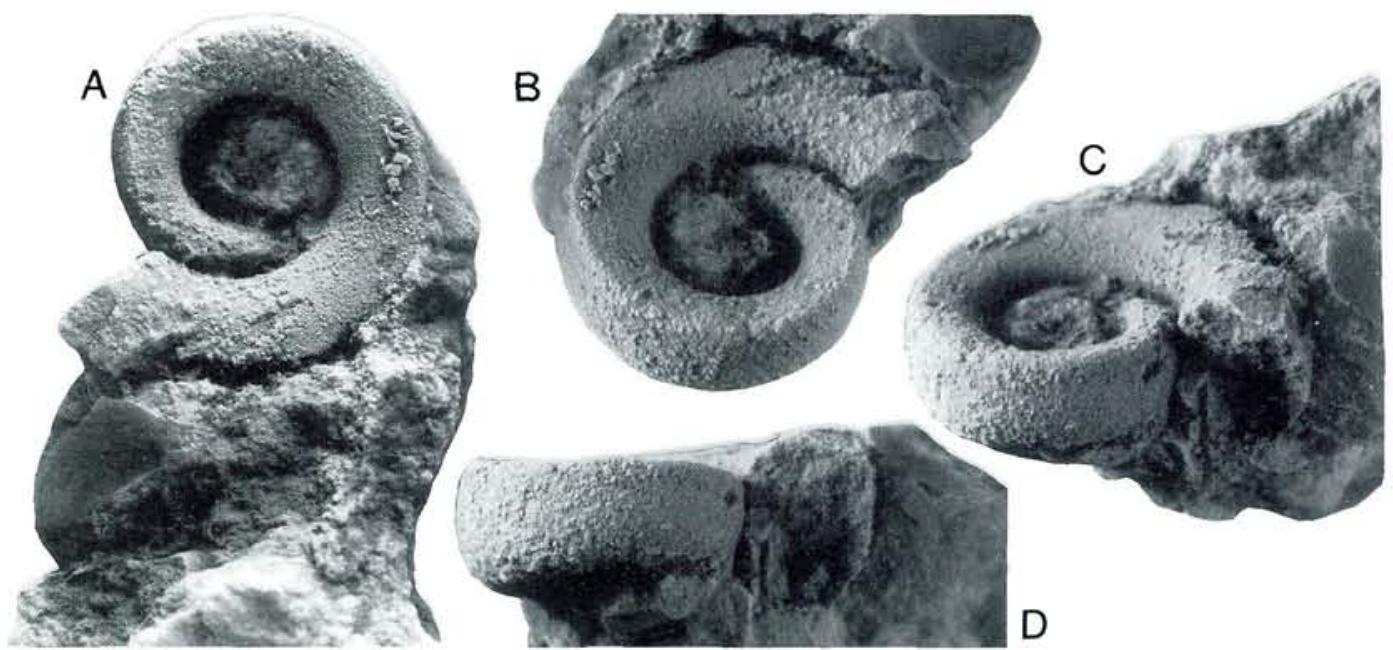

Fig. 10. Bridgeina sp. Poulsen Cliff Formation, MGUH 18.969 from GGU collection 206483, internal mould, all X5. A, apical view. $\mathrm{B}, \mathrm{C}$, oblique apical views. D, apertural view showing the elongate aperture and whorl profile.

Hintze (1952, pl. 9, fig. 18). P.? lata Zhou \& Fortey 1986 from the North China platform lacks a clearly demarcated cranidial and pygidial border. P. willistoni Lochman 1966 is known from pygidia only; these are narrower (tr.) than those of $P$. elegans, and with strongly furrowed pleural fields.

\section{Gastropoda}

\section{Genus Archinacella Ulrich \& Scofield 1897}

Type species. - Archinacella powersi Ulrich \& Scofield 1897

Discussion. - Although considered to be a monoplacophoran by Knight \& Yochelson (1960), Archinacella was referred to the Gastropoda by Starobogatov (1970) and Harper \& Rollins (1982).

Archinacella(?) cf. A. elongata (Cullison 1944) Fig. 9

Figured material. - MGUH 18.970 from GGU collection 206483 , the only known specimen.

Discussion. - This single specimen is an internal mould broken along the abapical margin. The apex clearly overhangs the adapical margin and the shell is curved through more than half a revo- lution. In plan view, the restored tear-shaped plan suggests that width was about two thirds of length. No traces of musculature are preserved, making the generic assignment uncertain; ornament and shell thickness are not known.

Cullison (1944) described two internal moulds from the Rich Mountain Formation of the Ozark Uplift which he assigned to Proplina elongata sp. nov. The holotype closely resembles the Poulsen Cliff specimen in lateral view, but appears more laterally compressed in plan view. It is on account of the strong curvature and overhanging aperture that this species is here placed in Archinacella, rather than retained within Proplina. The type of the latter genus, illustrated by Knight (1941, pl. 4 , fig. 2a-c), has a much more blunt apex and less tightly coiled shell. The assignment can only be tentative, however, since details of shell musculature are not known. Pilina has discrete paired muscle scars and is interpreted as a monoplacophoran related to Tryblidium and Pilina. The muscle scar in Archinacella is a thin continuous band passing beneath the apex which prompted Starobogatov (1970) and Harper \& Rollins (1982) to refer it to the Gastropoda. 


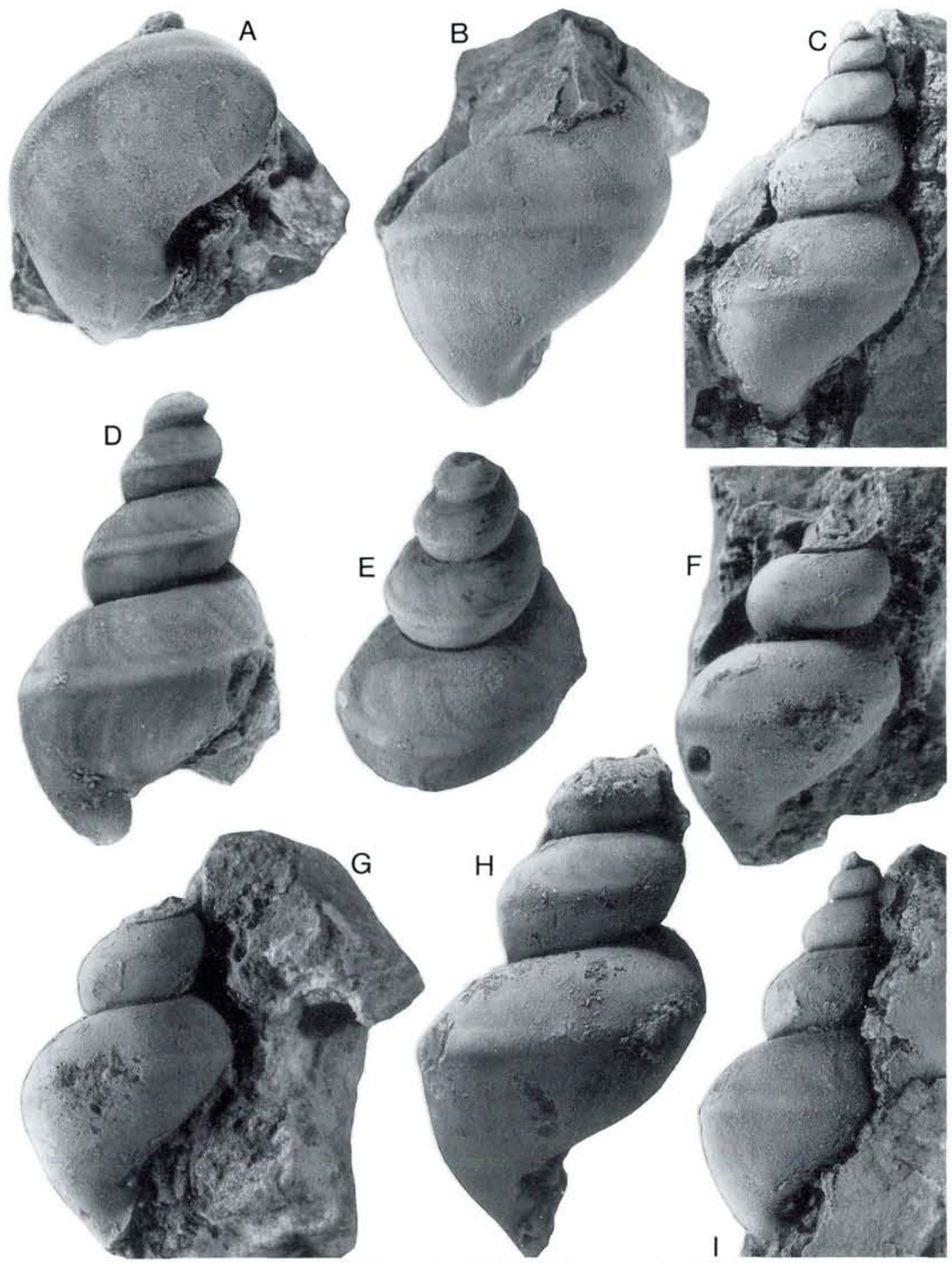

Fig. 11. Plethospira(?) floweri sp. nov. Poulsen Cliff Formation, GGU 206483, internal moulds, all X3. A, B, basal and lateral views to show prominent raised band and traces of growth ornament, MGUH 18.972. C, I, lateral views, MGUH 18.973. D. E. holotype in lateral and apico-lateral views showing band produced by selenizone and growth ornament, MGUH 18.974. F. G. lateral views, MGUH 18.975. H. lateral view, MGUH 18.976. 

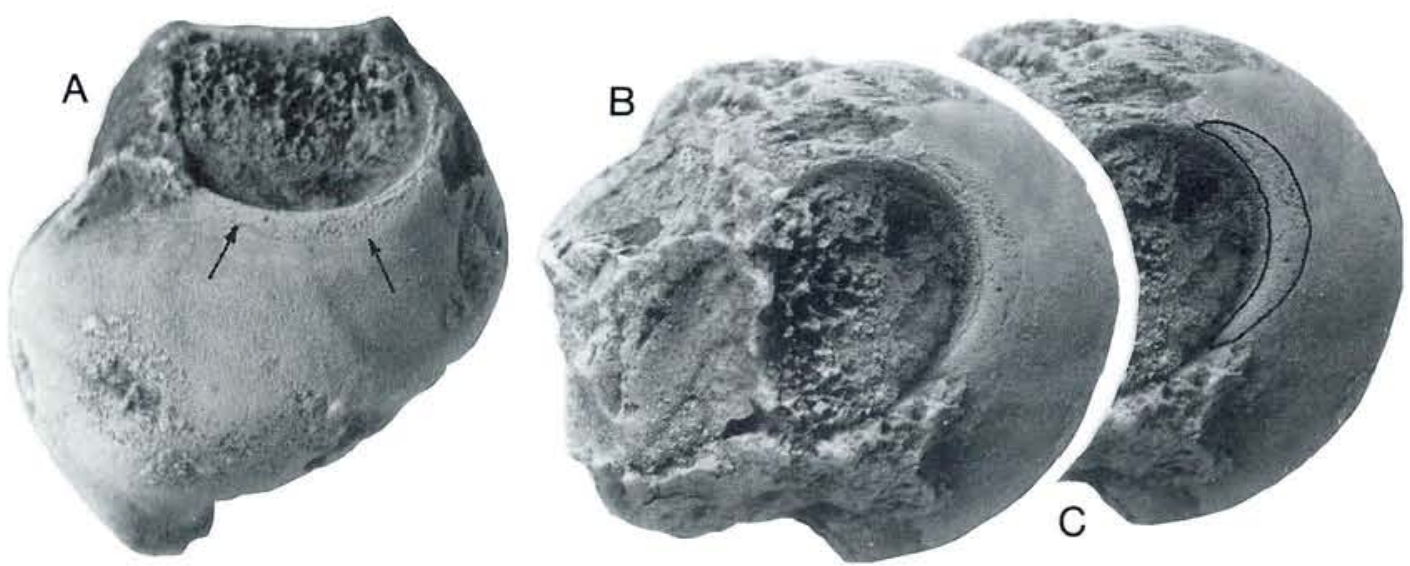

Fig. 12. Plethospira(?) floweri sp. nov. Poulsen Cliff Formation, MGUH 18.971 from GGU collection 206483, X6, internal mould with muscle scar. A, apico-lateral view with lower margin of muscle scar arrowed. B, C, apical view with outline of the crescentic scar inked in $\mathrm{C}$.

Genus Bridgeina Flower 1969a

Type species. - Bridgeina carinifera Flower 1969a

\section{Bridgeina sp.}

Fig. 10

Figured specimen. - MGUH 18.969 from GGU collection 206483.

Additional material. - A single poor external mould.

Discussion. - The single figured internal mould preserves only about 1 whorl; it is broken adaperturally and the early whorls are missing. The spire was clearly not raised above the final preserved whorl. The upper whorl surface is flattened near the angular, in later stages slightly carinate, junction with the outer whorl surface; it gradually increases in convexity toward the suture with the previous whorl. In standard orientation (fig. 10D) the outer whorl surface is vertical (i.e. parallel to the axis of coiling) and passes with increased curvature onto the uniformly convex, non-angulate base. Whorl cross-section (fig. $10 \mathrm{D})$ is thus essentially oval, with width about two-thirds of height, and with sub-parallel outer and umbilical walls; in detail, the umbilical wall is slightly concave medially due to the slight impression of the earlier whorl.

Shell ornamentation is poorly known; a few traces of adaperturally convex growth lines on the upper whorl surface at the suture indicate a shallow sinus at the whorl shoulder.

Bridgeina was described by Flower (1969a) from the El Paso Group of New Mexico with two constituent species, the type species $B$. carinifera Flower 1969a and $B$. rotunda Flower 1969a. The Greenland specimen most closely resembles $B$. carinifera, the whorl cross-section in $B$. rotunda being more equidimensional. The concave spire in both forms is proportionally slightly wider than in the Greenland species which also appears to expand more rapidly, in terms of height of the whorl.

Helicotoma uniangulata (Hall 1847), the type species of Prohelicotoma Flower 1969b, has more rounded whorls and a more uniformly convex outer whorl and base than Bridgeina sp. In addition, the carina on the upper surface is not peripheral (cf. Flower 1969b, pl. 6, fig. 28; Cloud \& Barnes 1948, pl. 40, figs 15-20).

Bridgeina was tentatively identified from the Wandel Valley Formation (Pyramideplateau Member) by Yochelson \& Peel (1975), but neither figured nor described.

Genus Plethrospira Ulrich in Ulrich \& Scofield 1897

Type species. - Holopea cassina Whitfield 1886

Plethrospira(?) floweri sp. nov.

Figs 11, 12. 
Derivation of name. - In memory of Rousseau H. Flower $(1913-1988)$.

Holotype. - MGUH 18.974 from GGU collection 206483.

Additional figured material. - MGUH 18.972 18.973, MGUH $18.965-18.966$, from the same collection as the holotype.

Other material. - About 18 fragmentary specimens in the same collection.

Description. - A moderately high spired gastropod with the relatively high rate of whorl translation producing a slender spire and only slight whorl embracement. The height of the final whorl, measured parallel to the axis of coiling at the latest growth stage, is almost half the total height. The nucleus and eary whorls are unknown. Later whorls are progressively divided into upper and lower surfaces at the angular periphery which is the locus of a raised band on the internal mould. The band lies at the mid-height of the exposed whorl face in the spire, but at just above mid-height of the full whorl face. The upper whorl surface is shallowly convex, sloping from the suture down, and outward (in standard orientation, fig. 10D) to the whorl periphery; a narrow sub-sutural shoulder is probably present. The lower whorl surface is uniformly shallowly convex prior to rapid, but not angular, passage onto the columellar wall which is parallel to the axis of coiling. The aperture is thus significantly higher than wide; umbilicus absent.

The outer lip is sinuate. Prosocline growth lines sweep back from the suture, increasing in curvature just prior to meeting the upper surface of the band; on the lower whorl surface growth lines curve gently forward away from the band prior to assuming a more orthocline form. While the basal junction between the outer and inner lips gives the impression of a shallow sinus on account of its rapid curvature, no deflection is observed in the course of the transverse growth lines.

The band is the locus of a slit which generates a selenizone. The length of the slit is not known, but it was probably short. Ornamentation of fine growth lines, apparently without spiral elements. Shell thickness and structure are unknown.

Discussion. - Plethospira(?) floweri is known only from internal moulds but these carry traces of growth ornamentation and the peripheral selenizone.

The general fusiform shape, with a tendency for the aperture to appear notched at its base, suggested that this species was a plethospirid murchisoniacean at first glance (Fortey \& Peel 1982). In view of the number of whorls and the raised band, however, only tentative assignment is made to Plethospira. P.(?) floweri combines features of high spired murchisoniid murchisoniaceans (the relatively high spire and large number of whorls), plethospirid murchisoniaceans (large final whorl, suggestion of anterior notch) and lophospirid pleurotomariaceans (tendency for whorls to be angular with the prominent band carrying the selenizone).

The absence of strong spiral angulations other than that carrying the selenizone and the relatively great height argue against assignment to the Lophospiridae Wenz 1938 members of which are mainly characteristic of Middle Ordovician and Silurian strata. Lophospirid shells are also commonly turbiniform and frequently (but not exclusively) carry angulations on the upper and lower whorl surfaces. An exception is provided by Donaldiella Cossmann 1903 (Middle Ordovician - Silurian) which is both high spired and lacks angulations other than that at the whorl periphery. P.(?) floweri is readily distinguished from the type species of Donaldiella, Goniospira filosa Donald 1902, in possessing a true slit and selenizone and less obliquely inclined growth lines on the upper and lower whorl surfaces. Only a deep V-shaped sinus, without a true slit, is present in $D$. filosa which also has much more strongly angulated whorls than P.(?) floweri (Knight 1941).

$P$.(?) floweri is a much more slender shell than the holotype of the type species of Plethospira, $P$. cassina (Whitfield 1886) from Fort Cassin, Vermont, as illustrated by Knight (1941, pl. 23, fig. $4 \mathrm{~b}$ ), although an accompanying topotype does show the development of the final whorl better. The rate of whorl expansion is higher than in the Greenland species and the final whorl accounts for about two-thirds of the total height. The final 
Fig. 13. Hormotoma sp. Poulsen Cliff Formation, GGU 206483, lateral views of internal moulds, all $\mathrm{X} 3$

A. MGUH 18.977 .

B, MGUH 18.978 .

C, MGUH 18.979 .
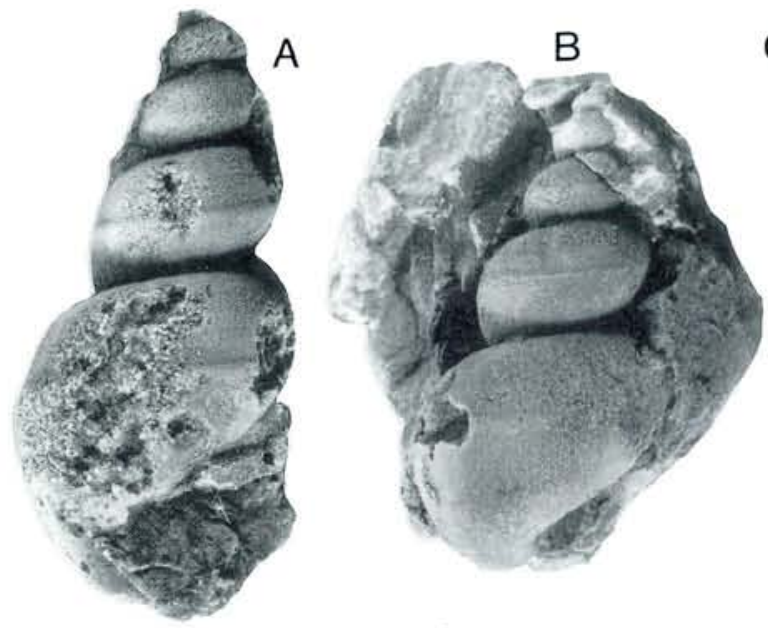

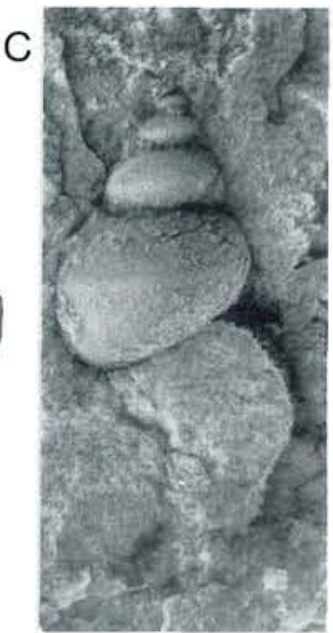

whorl of P. extensa Heller 1954 from the Roubidoux Formation of Missouri is reminiscent of P.(?) floweri but the former species lacks the angular periphery and is more rapidly expanding (Heller 1954). P. bilineata Flower $1969 \mathrm{c}$ from the Fort Ann limestone of New York has fewer, more rapidly expanding and uniformly convex whorls than P.(?) floweri (Flower 1969c).

Cullison (1944) figured several high spired gastropods from the Lower Ordovician of the Ozarks but none of the species, which he assigned to Hormotoma Salter 1859, compare closely with P.(?) floweri. H. dubia Cullison 1944 does have a similar band at mid-whorl and also a relatively high rate of whorl translation; its lower rate of whorl expansion, however, clearly separates it from the Greenland species.
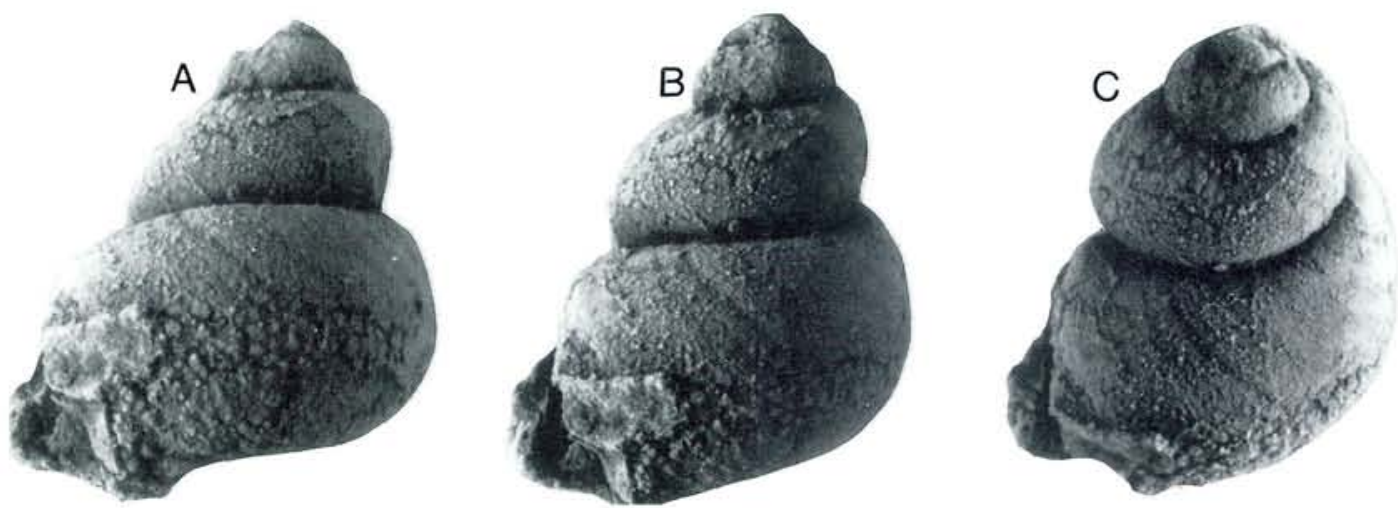

Fig. 14. Sinuopea sp. Poulsen Cliff Formation, MGUH 18.980 from GGU collection 206483, all X8. A, slightly oblique lateral view showing the broad sinus delimited by growth lines. B, lateral view. C, apico-lateral view.

Hormotoma cannonensis Stauffer 1937a, known from a single tiny (height $6 \mathrm{~mm}$ ) fragment from the Shakopee dolomite, seems to show a similar whorl profile to $P$.(?) floweri. Ornamentation is poorly known but there is some suggestion of a deeper sinus than in P.(?) floweri (Staufer 1937a).

One of the available specimens of P.(?) floweri preserves an elongate muscle scar near to the suture with the previous whorl (fig. 12). In view of its position, it is likely that a second scar was also present at the columellar, near the base of the whorl. 

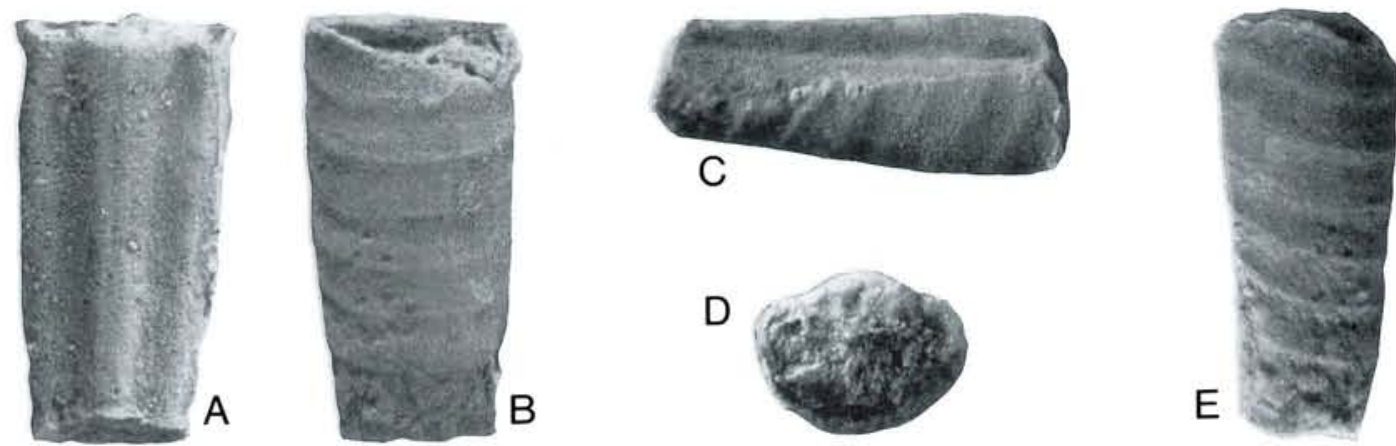

Fig. 15. Undetermined hyolith. Poulsen Cliff Formation, MGUH 18.981 from GGU collection 206483, all X8. A, dorsal view. B, ventral view, note the adapical concavity of the varices. C, lateral view. D, cross-sectional profile showing the trilobed dorsal surface (upper) produced by the longitudinal sulci. E, oblique ventral view.

Genus Hormotoma Salter 1859

Type species. - Murchisonia gracilis Hall 1847

\section{Hormotoma sp.}

Fig. 13

Figured material. - MGUH 18.977 - 18.979 from GGU collection 206483.

Additional material. - About 4 specimens in the same collection.

Discussion. - Three figured internal moulds are placed within Hormotoma. Two of these show convex whorls, a raised band suggestive of a selenizone and the faint impressions of steeply inclined growth lines on the upper whorl surface; the latter suggest a shallow sinus at mid-whorl (fig. 13B-C). The third specimen has a more flattened outer whorl surface and more slender form but poor preservation does not allow unequivocal separation of the two forms.

None of the several species from the Lower Ordovician of the Ozarks which Cullison (1944) assigned to Hormotoma appears close to these Poulsen Cliff specimens. Hormotoma artemesia (Billings) of Stauffer (1937b) from the Shakopee dolomite of Minnesota has a more slender form with less rapidly expanding whorls and a deeper sinus.
Genus Sinuopea Ulrich 1911

Type species. - Holopea sweeti Whitfield 1880

Sinuopea sp.

Fig. 14

Figured specimen. - MGUH 18.980 from GGU collection 206483.

Additional material. - One poor specimen.

Discussion. - This single small figured specimen (height $6 \mathrm{~mm}$ ) preserves the turbinate form and sinuate aperture characteristic of Sinuopea. The small size and low number of whorls suggest a juvenile shell. Matrix adhering to the final growth stage at mid-whorl (fig. 14A) suggests an infilled slit. However, the course of the growth lines on the basal surface strongly suggests that the supposed slit is spurious and that a sinus without slit (as in Sinuopea) is present. The presence of a slit would otherwise indicate relationship to Taeniospira Ulrich \& Bridge 1931.

Sinuopea sp. is slightly higher spired than the type species from the Upper Cambrian of Wisconsin, with less deeply incised sutures. In addition, growth lines sweep more obliquely backward from the suture. S. cingulata Ulrich \& Bridge 1931 and S. vera Ulrich \& Bridge 1931 . from the Lower Ordovician Van Buren Formation of Missouri, show similar obliquity of ornament on the upper whorl surface to Sinuopea sp. but have wider, umbilicate shells (Ulrich \& Bridge 1931). 
Sinuopea whittardi Poulsen 1937, from the Antiklinalbugt Formation (Early Ordovician age) of East Greenland also has a wider shell than the Poulsen Cliff Formation specimen.

\section{Hyolitha}

Discussion. - Runnegar et al. (1975) recognised the hyoliths as a new phylum to which Sysoyev (1984) gave the name Hyolithozoes. Marek \& Yochelson (1976) presented arguments for considering hyoliths to be molluscs; for convenience this interpretation is followed here.

\section{Undetermined hyolith}

Fig. 15

Figured material. - MGUH 18.981 from GGU collection 206483.

Discussion. - This single fragment is broken at both extremities; it is slightly curved along its plane of symmetry with the presumed dorsal surface shallowly concave in long profile. In crosssection the dominant ventral surface is uniformly convex while the dorsal surface is trilobed on account of two longitudinal sulci located one on each side of a median ridge; the junction between the ventral and dorsal surfaces lies above the point of maximum width (fig. 15D). The ventral surface is ornamented with conspicuous curved varices which are uniformly spaced and separated by shallowly concave areas. The varices are convex adapically, curving toward the narrow end of the fragment from the junction with the dorsal surface. No growth lines or other ornamentation are visible on the conch.

The longitudinal dorsal sulci and cross-section are reminiscent of the type species of Hyolithes Eichwald 1840, Hyolithes acutus Eichwald 1840 from the Lower Ordovician of the Baltic region, as illustrated by Holm (1893), although the dorsal surface is more inflated, with more prominent trilobation than in the Baltic species. Hyolithes sp. 12 of Holm, from the Ordovician of Öland, shows a similar dorsal profile to the Greenland specimen but has a less expanded ventral surface.

The status of this specimen is made uncertain by the nature of the varices. Their adapical convexity (presuming the narrower end of the preserved fragment to be apical) suggests that the ventral aperture was excavated into a broad sinus, rather than extended into the shelf-like ligua characteristic of members of the Order Hyolithida. True growth lines, however, have not been discerned.

Acknowledgements. Type and figured specimens are deposited in the type collection of the Geological Museum, Copenhagen (MGUH prefix). Other material (GGU prefix) is retained in the collections of the Geological Survey of Greenland (Grønlands Geologiske Unders $\emptyset$ gelse, GGU). Publication is approved by GGU. Paul Smith and Stuart Watt commented on the manuscript; Poul Schiøler provided the Danish summary.

\section{Dansk sammendrag}

Fra Poulsen Cliff Formation i Washington Land beskrives en velbevaret lavt-vands fauna af nedre ordovicisk alder. Faunaen består af bathyuride trilobitter samt associerede gastropoder og en ubestemt hyolith. Der opstilles to bathyuride arter, Licnocephala sminue sp. nov. og Peltabellia elegans sp. nov., samt gastropodarten Plethospira(?) floweri sp. nov. Biolgina Maximova betragtes her som et junior synonym for Peltabellia Whittington. Den geografiske udbredelse af slægten Peltabellia er et eksempel på de tætte relationer mellem lavt-vands trilobit faunaerne i Laurentia og den nordøstlige del af den sibiriske platform.

\section{References}

Billings, E. 1865: Palaeozoic fossils. Vol. 1. Containing descriptions and figures of new or little known species of organic remains from the Silurian rocks, 1861-1865. Montreal: Geol. Survey Canada, $426 \mathrm{pp}$.

Boyce, W. D. 1983: Preliminary Ordovician trilobite biostratigraphy of the Eddies Cove west - Port au Choix area, western Newfoundland. Dept. Mines Energy Newf. Labrador, Current Research Rept. 83-1, 11-15.

Chugaeva, M. N. 1968: Trilobiti In: Balashov, Z. G., Vostakova, V. A., Elti'sheva, R. S., Obut, A. M., Oradovskaya, M. M., Preobrazhenskiy, B. V., Rozman, Kh. S., Sobolevskaya, R. F. \& Chugaeva, M. N. 1968: Polevoi atlas ordoviskoi fauni Severo-Vostoka SSSR. Magadanskoi Kinzhnoi Izdat. 143 pp.

Chugaeva, M. N. 1973: Trilobiti In: Chugaeva, M. N., Ivanova, V. A., Oradovskaya, M. M. \& Yakovlev, V. Biostratigrafiya nizhnei Chasti Ordovika Severo-Vostoka SSSR i biogeografiya kontsa ranneko Ordovika. Trudy geol. Inst. SSSR 213, 286 pp.

Cloud, P. E. \& Barnes, V. E. 1948: The Ellenburger Group of Central Texas. Univ. Texas publ. 4621,473 pp.

Cowie, J. W. \& Adams, P. J. 1957: The geology of the CambroOrdovician rocks of central East Greenland. Meddr Grønland $153,1,193 \mathrm{pp}$.

Cullison, J. S. 1944: The stratigraphy of some Lower Ordovician formations of the Ozark uplift. Univ. Missouri School Min. Metall. Tech. Ser. 15, 2, 102 pp.

Flower, R. H. 1969a: Some El Paso guide fossils. Mem. New Mexico Bur. Mines Min. Res. 32, 1-19.

Flower, R. H. 1969b: Fossils from the Smith Basin Limestone of the Fort Ann region New York. Mem. New Mexico Bur. Mines Min. Res. 32, 21-27.

Flower, R. H. 1969c: Fossils from the Fort Ann Formation. Mem. New Mexico Bur. Mines Min. Res. 32, 21-27. 
Fortey, R. A. 1979: Early Ordovician trilobites from the Catoche Formation (St George Group), western Newfoundland, Bull. geol. Surv. Canada 321, 61-114.

Fortey, R. A. 1986: Early Ordovician trilobites from the Wandel Valley Formation, eastern North Greenland. Rapp. Gronlands geol. Unders. 132, 15-25.

Fortey, R. A. \& Peel, J. S. 1982: Fossils from the Poulsen Cliff Formation, Washington Land, western North Greenland. Rapp. Grønlands geol. Unders. 108, 24 (only).

Fortey, R. A. \& Peel, J. S. 1983: The anomalous bathyurid trilobite Ceratopeltis and its homeomorphs. Spec. Pap. Palaeontology 30, 51-57.

Harper, J. A. \& Rollins, H. B. 1982: Recognition of Monoplacophora and Gastropoda in the fossil record: a functional morphological look at the bellerophont controversy. Proc. 3rd North Am. Paleont. Conv. 1, 227-232.

Heller, R. L. 1954: Stratigraphy and paleontology of the Roubidoux Formation of Missouri. Missouri Geol. Surv. Water Res. 2nd ser., 35, 112 pp.

Higgins, A. K., Ineson, J. R., Peel, J. S., Surlyk, F. \& Sønderholm, M. in press: The Franklinian basin in North Greenland. In: Trettin, H. P. (edit.) The Innuitian region. The Geology of North America vol. E. Ottawa: Geol. Surv. Canada.

Hintze, L. F. 1952: Lower Ordovician trilobites from western Utah and eastern Nevada. Bull. Utah geol. mineral. Surv. $48,249 \mathrm{pp}$.

Holm, G. 1893: Sveriges kambrisk-siluriska Hyolithidx och Conularida. Sveriges geol. Unders. ser. C, 112, 172 pp.

Ineson, J. R. \& Peel, J. S. 1987: Cambrian platform - outer shelf relationships in the Nordenskiöld Fjord region, central North Greenland. Rapp. Grønlands geol. Unders. 133, .13-26.

Kerr, J. W. 1967: New nomenclature for Ordovician rock units of the eastern and southern Queen Elizabeth Islands, Arctic Canada. Bull. Can. Petrol. Geol. 15, 91-113.

Kerr, J. W. 1968: Stratigraphy of central and eastern Ellesmere Island, Arctic Canada. Part II. Ordovician. Pap. geol. Surv. Can. 67-27(2), 92 pp.

Knight, J. B. 1941: Paleozoic gastropod genotypes. Spec. Pap. geol. Soc. Am. 32, 510 pp.

Knight, J. B. \& Yochelson, E. L. 1960: Monoplacophora. In: Moore, R. C. (edit.) Treatise on invertebrate paleontology I, Mollusca 1, Kansas: Geol. Soc. Am. and Univ. Kansas Press, 177-184.

Marek, L. \& Yochelson, E. 1. 1976: Aspects of the biology of Hyoliths (Mollusca). Lethaia 9, 65-82.

Maximova, Z. A: 1955: Klass Trilobita - Trilobitii In: Nikiforova, O. I. (edit.) Polevoi atlas ordovikskoi i siluriiskoi fauny sibirskoi platformy. Vses. Nauchno-Issled. geol. Inst. (VSEGEI), Moscow, 117-135.

Maximova, Z. A. 1962: Trilobiti ordovika i silura sibirskoi platformy. Trudy. Nauchno-Issled. geol. Inst. (VSEGEI) $76,215 \mathrm{pp}$.

Mossop, G. D. 1979: The evaporites of the Ordovician Baumann Fiord Formation, Ellesmere Island. Bull. geol. Surv. Canada 298, 52 pp.

Peel, J. S. \& Christie, R. L. 1982: Cambrian-Ordovician plat- form stratigraphy: correlations around Kane Basin. Meddr Grønland, Geosci. 8, 117-135.

Peel, J. S. \& Smith, M. P. 1968: The Wandel Valley Formation (Early-Middle Ordovician) of North Greenland and its correlatives. Rapp. Grønlands geol. Unders. 137.

Poulsen, C. 1927: The Cambrian, Ozarkian and Canadian faunas of Northwest Greenland. Meddr Grønland 70, 1(2), 233-343.

Poulsen, C. 1937: On the Lower Ordovician faunas of East Greenland. Meddr Gronland 119, 3, 72 pp.

Ross, R. J. 1951: Stratigraphy of the Garden City Formation in northeastern Utah and its trilobite faunas. Bull. Peabody Mus. nat. Hist. 6, 155 pp.

Ross, R. J. 1953: Additional Garden City (Early Ordovician) trilobites. J. Paleont. 27, 633-646.

Rozova, A. V. 1968: Biostratigrafiya i trilobiti verkhnego kembriya i nizhnego ordovika Severo-Zapada Sibirskoi platformy. Trudy Inst. Geol. Geofiz. Sibir. Otdel. 36, $191 \mathrm{pp.}$

Runnegar, B., Pojeta, J., Morris, N. J., Taylor, J. D., Taylor, M. E. \& McClung, G. 1975: Biology of Hyolitha. Lethaia 8, 181-191.

Starobogatov, Ya. I. 1970: Systematics of Early Paleozoic Monoplacophora. Paleont. J. 1970, 3, 293-302.

Stauffer, C. R. 1937a: A diminutive fauna from the Shakopee dolomite (Ordovician) at Cannon Falls, Minnesota. J. Paleont. 11, 55-60.

Stauffer, C. R. 1937b: Mollusca from the Shakopee dolomite (Ordovician) at Stillwater, Minnesota. J. Paleont. 11, 61-68.

Sysoyev, V. A. 1984: The morphology and systematic position of the hyoliths. Paleont. J. 1984, 2, 1-10.

Troelsen, J. C. 1950: Contributions to the geology of Northwest Greenland, Ellesmere Island and Axel Heiberg Island. Meddr Grønland 149, 7, 86 pp.

Twenhofel, W. H. 1938: Geology and palaeontology of the Mingan Islands, Quebec. Spec. Pap. geol. Soc. Am. 11, $105 \mathrm{pp}$.

Ulrich, E. O. \& Bridge, J. B. 1931: Gastropoda In: Ulrich, E. O., Foerste, A. F. \& Bridge, J. Systematic paleontology. Missouri Bur. Geol. Mines, 2nd ser. 24, 186-222.

Vostokova, V. A. 1955: Klass Gastropoda - bryukhonogie. In: Nikiforova, O. I. (edit.) Polevoi atlas ordovikskoi i siluriiskoi fauny sibirskoi platformy. Vses. Naucho-Issled. geol. Inst. (VSEGEI), Moscow, 82-86.

Vostokova, V. A. 1962: Ordovikskie i siluriiskie gastropody sibirskoi platformy. Trudy Vses. Naucho-Issled. geol. Instit. (VSEGEI) nov. ser. 75, 1-46.

Whittington, H. B. 1953: North American Bathyuridae and Leiostegiidae (Trilobita). J. Paleont. 27, 647-678.

Whittington, H. B. 1963: Middle Ordovician trilobites from Lower Head, western Newfoundland. Bull. Mus. comp. Zool., Harvard 129, 118 pp.

Yochelson, E. L. \& Peel, J. S. 1975: Ceratopea and the correlation of the Wandel Valley Formation, eastern North Greenland. Rapp. Gronlands geol. Unders. 75, 28-31.

Zhou Z-Y \& Fortey, R. A. 1986: Ordovician trilobites from North and Northeast China. Palaeontographica A 192 , 157-210. 